\title{
Microstructural, modal and geochemical changes as a result of granodiorite mylonitisation - a case study from the Rolovská shear zone (Čierna hora Mts, Western Carpathians, Slovakia)
}

\author{
Roman Farkašovský1 ${ }^{*}$, Katarína Bónová \& Marián Košuth ${ }^{3}$ \\ ${ }^{1}$ Institute of Geosciences, Faculty of Mining, Ecology, Process Control and Geotechnology, Technical University of \\ Košice, Letná 9, 04001 Košice, Slovakia \\ ${ }^{2}$ Institute of Geography, Faculty of Science, Pavol Jozef Šafárik University, Jesenná 5, 04001 Košice, Slovakia \\ 3State Geological Institute of Dionýz Štúr, Jesenského 8, 04001 Košice, Slovakia \\ *corresponding author, e-mail: roman.farkasovsky@tuke.sk
}

\begin{abstract}
Strong tectonic remobilisation and shear zone development are typical features of the easternmost part of the Veporicum tectonic unit in the Western Carpathians. The granodiorite mylonites in the area of the Rolovská shear zone (Čierna hora Mts) underwent a complex polystage evolution during the Hercynian and Alpine orogenies. Deformation during the latter reached greenschist facies under metamorphic conditions. Mylonites are macroscopically foliated rocks with a stretching lineation and shear bands. Structurally different mylonite types, ranging from protomylonites to ulramylonites with typical grainsize reduction from the margins towards the shear zone centre, have been assessed. The modal mineralogy of the different mylonite types changes considerably. Typical is a progressive decrease in feldspar content and simultaneously the quartz and white mica content increases from protomylonites towards the most strongly deformed ultramylonites. The deformation had a brittle character in less deformed rocks and a ductile one in more deformed tectonites. Obvious chemical changes occur in mesomylonites and ultramylonites. During mylonitisation, the original biotite granodiorite was depleted of $\mathrm{Mg}, \mathrm{Fe}, \mathrm{Na}, \mathrm{Ca}$ and $\mathrm{Ba}$, while $\mathrm{K}, \mathrm{Rb}$ and mainly Si increased considerably. Other (major and trace) elements reflect erratic behaviour due to lateral mobility. Chemical changes indicate the breakdown and subsequent recrystallisation of biotite and feldspars and, in turn, the crystallisation of albite and sericite. REE decrease in ultramylonites due to the breakup of accessory minerals during deformation and alteration.
\end{abstract}

Keywords: shear zone, protomylonite, mesomylonite, ultramylonite, Veporic unit

\section{Introduction}

Shear deformation in the Earth's crust is generally situated in planar shear zones that accommodate movement of relatively rigid wall-rock blocks. Slip along discrete fault zones and brittle deformation at lower metamorphic conditions is typical in the upper crust. In the middle and lower crust shear deformation is distributed over more diffuse zones with a ductile character of deformation at higher metamorphic conditions (Sibson, 1977; Passchier, 1982). Shear zone nucleation can start in pre-existing zones of inherent weakness, e.g., brittle structures, faults, joints or veins (Christiansen \& Pollard, 1997; Guermani \& Pennacchioni, 1998; Mancktelow \& Pennacchioni, 2005; Pennacchioni \& Mancktelow, 2007). Further development of the ductile mylonite shear zone requires maintenance of a weak rheology in a relatively narrow domain that is accompanied by structural, modal and geochemical changes 
of the original rocks (Rutter, 1999). Mylonite zones at the surface represent fossil ductile high-strain shear zones that were exhumed during subsequent geological evolution (Guermani \& Pennacchioni, 1998).

In general, mylonites have strong foliation and lineation that is already visible at macroscopic scale. Textures of polycrystalline rocks, e.g., granitoids, change by effect of shear deformation from protomylonites to ultramylonites with a progressive reduction of grainsize (Sibson, 1977; Simpson, 1985). Grainsize reduction during mylonitisation of granitoid rocks can be accomplished at first through whole-rock cataclasis and subsequently through ductile flow (Goodwin \& Wenk, 1995). A variety of microstructures can develop in naturally deformed rocks (Passchier \& Trouw, 1996) and are indicative of the metamorphic grade at which deformation took place (Pryer, 1993). Weak rheology is supported also by formation of fine-grained polyphase mineral aggregates, often with preferred orientation and by mutual connection of dispersed weak mineral phases (Stunitz \& Tullis, 2001; Oliot et al., 2010; Goncalves et al., 2012). A softening effect can be promoted by fluid-assisted reactions and by mineral transformations due to syn-kinematic metamorphism (Wintsch et al. 1995; Tullis et al., 1996; Wibberley, 1999; Sassier et al. 2006). Softening reactions during mylonitisation of granitoid rocks can be mica production at the expense of feldspar (Hippertt, 1998; Gueydan et al., 2003).

Fluid activity is very important in many geological processes related to metamorphism and metasomatism (e.g., van der Straaten et al., 2012; Halama et al., 2014). Deformation at low-grade metamorphic conditions enables $\mathrm{H}_{2} \mathrm{O}$-rich fluid migration in the shear zones through wetted crystal-fluid microstructures, e.g., microfractures and grain boundaries (Lee et al., 1991; Goddard \& Evans, 1995). In contrast, deformation under medium to high metamorphic grades has a relatively dry character (Bell \& Cuff, 1989). Fluid activity plays an important role during deformation in the shear zones. Fluids may enable dissolution of some minerals (quartz, feldspar, carbonates) and transfer of chemical components $\left(\mathrm{SiO}_{2}\right.$, alkalies) in the shear zone (Selverstone et al., 1991; Hippertt, 1994, 1998; Goddard \& Evans, 1995). Pressure of fluids enhances propagation of brittle fractures. During ductile deformation fluids enhance crystal plasticity and dynamic recrystallisation (Tullis \& Yund, 1989). Low-grade metamorphism in the presence of fluids can catalyse softening reactions with the production of phyllosilicates, e.g., white mica and chlorite (Wintsch et al., 1995; Wibberley, 1999; Arancibia \& Morata, 2005). Mass transfer during deformation can cause marked volume changes in the shear zones. Shear deformation accompanied by volume-loss is characteristic of compressional tectonic regimes, while volume-gain mylonitic zones are more typical of extensional tectonic regime (Hippertt, 1998) where fluid-enhanced silicification is common (Roberts \& Nissen, 2006).

In the present contribution microstructural, modal and geochemical data obtained from the Rolovská shear zone in the Čierna hora Mts are presented. This zone was active during several deformational stages, involving both compressional and extensional regimes. The final movements in the extensional regime were the result of stress relaxation after contraction in the area. The aim of our study was to present a synthesis of microstructural, modal and geochemical changes observed in the gradually strained rocks from the undeformed and unaltered protolith to the strongly deformed ultramylonite. Attention was paid also to transfer of chemical components in the shear zone and to possible volume changes during deformation.

\section{Geological setting and evolution of the area}

The Čierna hora Mts are located in the eastern part of the Western Carpathians, northwest of the town of Košice (Fig. 1) and are part of Slovenské rudohorie Mts. In terms of geology the Čierna hora Mts belong to the Veporicum tectonic unit of the Western Carpathians. The Veporic unit comprises the Slovenské rudohorie Mts and the Král'ovohol'ské Tatry Mts crystalline basement in the west, as well as the Čierna hora Mts in the east. Strong Alpine remobilisation is typical of the Veporic tectonic domain. The dynamo-metamorphosed, mylonitised granitoid rocks were studied in detail mainly in the western part of the Veporicum by Miko et al. (1982), Putiš et al. (1997) and Kohút et al. (2000). Those authors observed that mylonitic deformation of the granitoid rocks had a penetrative character with development of wide shear zones similarly as in the Čierna hora Mts.

The Čierna hora Mts consist of a crystalline complex, Upper Palaeozoic to Mesozoic cover formations and isolated klippes of the Choč nappe (Hronicum Unit). The Veporicum of the Čierna hora Mts is separated from the Gemeric unit in the southwest by Margecany shear zone. In the north it is transgressively covered by sediments of the central-Carpathian Paleogene Basin, in the south and east by sediments of the eastern Slovakian Neogene Basin. 


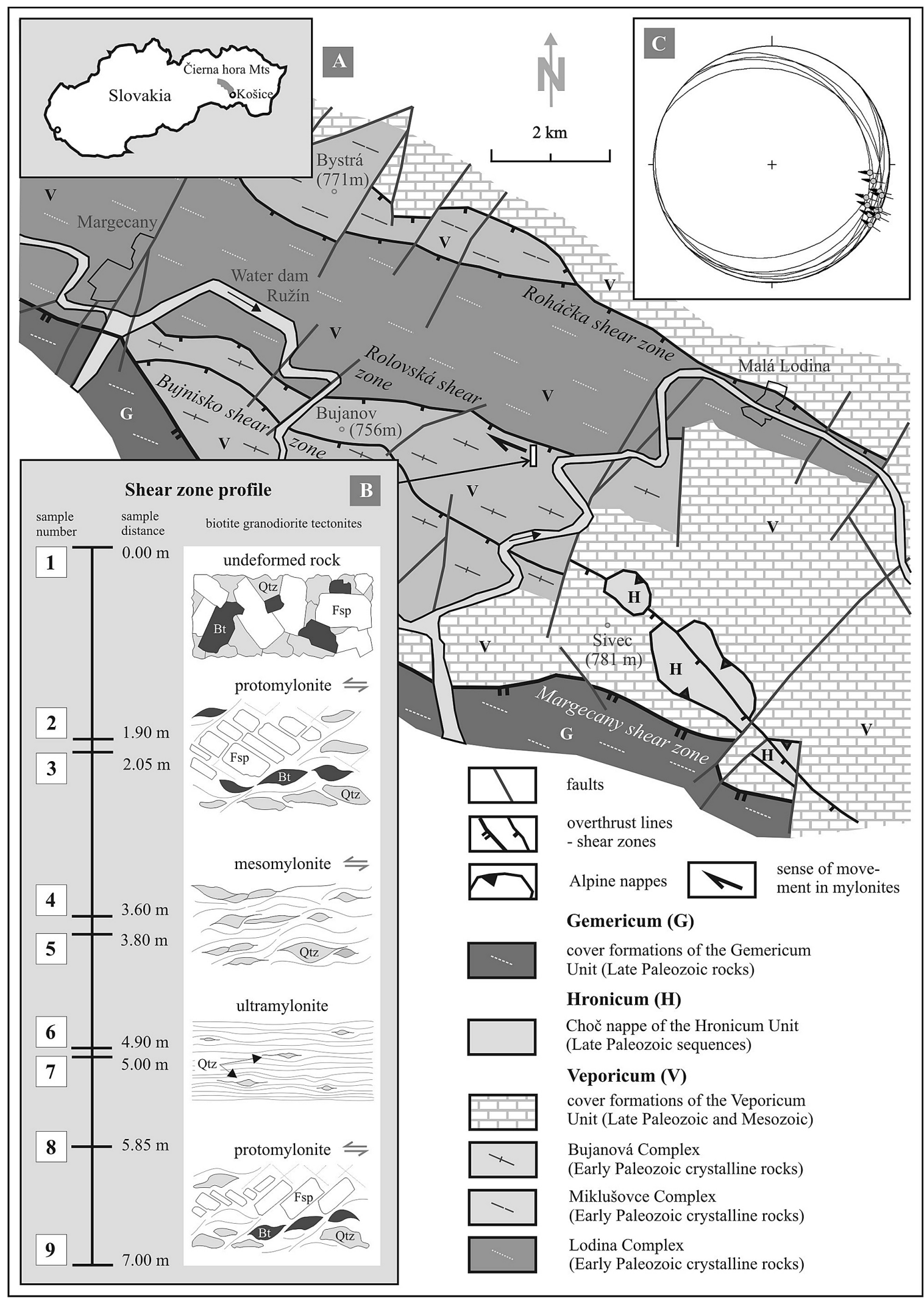

Fig. 1. A - Simplified geological map of the Čierna hora Mts and adjacent area with the position of the section studied; B - scheme of the same; C - tectonogram of predominant mylonite foliation planes and stretching lineations on these. Microscopic sense-of-shear markers indicate movement of the hanging wall of the shear zone towards the northwest. 
The pre-Carboniferous crystalline basement of the Čierna hora Mts consists of three local lithostructural complexes: the Lodina Complex, the Miklušovce Complex and the Bujanová Complex (Jacko, 1985). The Western Carpathian crystalline basement was divided into the three basic Hercynian lithotectonic units (compare Bezák, 1994). According to analogical lithology and T-P parameters of the Hercynian metamorphism the Lodina Complex is correlated with the Middle lithotectonic unit (MLU), while the Miklušovce and Bujanová complexes correspond with the Upper lithotectonic unit (ULU) of the Tatroveporic Hercynian structure (Jacko et al., 1995).

The Lodina Complex (Fig. 1A) is formed mainly by intensively diaphtorised gneisses, mica schists and local intrafolial amphibolite bodies, which are the products of Hercynian metamorphism (Jacko, 1985). T-P conditions of the Hercynian metamorphism reached temperatures of $520-540{ }^{\circ} \mathrm{C}$ and a pressure of up to $300 \mathrm{MPa}$ (Korikovskij et al., 1990). The complex tectonic processes caused multiple repetition of rock types in the Lodina complex profile as well as wide rock mylonitisation.

The Miklušovce Complex (Fig. 1A) comprises migmatites, gneisses and amphibolites developed during the same phase of the Hercynian synkinematic metamorphism. The complex was penetrated later by intrafolial bodies of aplite granites (Jacko, 1985). The Hercynian metamorphism reached T-P conditions of amphibolite facies with temperatures of $570-610^{\circ} \mathrm{C}$ and pressures of $530-600 \mathrm{MPa}$ (Korikovskij in Krist et al., 1992). The rocks of the Miklušovce complex were thrust onto the Lodina Complex during Hercynian orogeny. The tectonic contact of both complexes was repeatedly reactivated by Alpine shear zones (Jacko in Polák et al., 1997).

The Bujanová Complex (Fig. 1A) is formed mainly by intrusions of late-orogenic Hercynian granitoids which penetrate older metamorphic structures (Jacko, 1975, 1985). Metamorphic rocks, especially biotite gneisses, ophthalmic migmatites and amphibolites participate in the complex composition to a lesser extent. They are products of Hercynian periplutonic metamorphism. The temperatures varied between $620-625^{\circ} \mathrm{C}$, pressures between 400- $450 \mathrm{MPa}$ (Jacko et al., 1990). The rocks of the Bujanová Complex are strongly tectonically deformed, having developed a wide variety of brittle to brittle-ductile tectonites of granitoid rocks (Jacko, 1975, 1985; Jacko et al., 1996; Jacko in Polák et al., 1997).

The Upper Carboniferous detritic metasediments rest on the crystalline complexes. A significant part of these rocks is strongly dynamically met- amorphosed in the shear zone in the contact area of the crystalline complexes with cover formations (Vozárová \& Jacko in Polák et al., 1997). The cover formations comprise Permian clastic, volcanic and volcaniclastic rocks and Triassic and Jurassic carbonate and clastic sediments. Upper Palaeozoic rocks of the Hronic unit are preserved in the form of isolated Choč nappe klippes on the cover formations of the Čierna hora Mts.

The geological setting of the Čierna hora Mts is a product of several Hercynian, but mainly Alpine, tectonometamorphic stages (Jacko, 2007). During the Hercynian orogeny the ULU (Miklušovce and Bujanová complexes) was thrust onto the MLU (Lodina complex) southvergently which was accompanied by syntectonic metamorphism in amphibolite facies T-P conditions (Korikovskij et al., 1990; Jacko et al., 2001; Jacko, 2007). Next the intrafolial granitoid bodies were emplaced into the ULU. An age of $357 \pm 3$ Ma was obtained from the Čierna hora Mts biotite tonalite (Broska et al., 2013). The biotite granodiorites of the section studied are a product of this stage. Intrusions of granitoid bodies led to extensive periplutonic changes of rocks of the (ULU) also under metamorphic conditions of the amphibolite facies (Korikovskij et al., 1990). Consequently the ULU was rethrust further to the south (Jacko et al., 2001; Jacko, 2007). The mesoscopic structures of the stages mentioned are E-W-oriented folds as well as their axial plane cleavage sets representing the pre-Alpine subhorizontal schistosity.

During Alpine orogeny tectonic evolution was influenced by compression at first with typical a north-east vergent area reduction. The superficial Choč nappe was thrust onto the Veporic unit (Jacko, 1988) and the rock complexes of the Gemericum were emplaced onto the slope of the Veporic unit (Jacko, 2007). The rocks of the Veporicum, with adjacent parts of the Gemeric unit and the Choč nappe, were folded penetratively into mesoscopic to regional NW-SE folds (Jacko, 1975). Subsequent$1 y$, the imbrication structure was formed and the NW-SE shear zones and Alpine cleavage came into being, dipping usually to the southwest (Jacko et al., 1996, 2001; Jacko, 2007). The limit of the Alpine mineral parageneses is 135.7 Ma Ar/Ar muscovite age from granite mylonite of the Bujanová Complex (Maluski et al., 1993). The older structures, lithological boundaries and tectonic zones were reactivated (Jacko, 1975; Jacko et al., 1996). The development of mylonitic shear zones in granitic rocks where shear was localised along pre-existing zones of weakness (aplite dykes, joints, veins, cataclasite zones) was described by Christiansen \& Pollard (1997), Guermani \& Pennacchioni (1998) and others. 
The next movements in the shear zones were linked to the uplift of the Veporic basement and subsequent south-vergent extensional unroofing (Németh et al., 2000; Németh, 2001). Shear zones were opened and hydrothermally silicified (Jacko \& Baláž, 1993; Jacko, 2007). Post-collisional unroofing in the western part of the contact zone of the Gemericum with the Veporic unit was dated as mid-Cretaceous (Plašienka, 1999). Finally, the NW-SE shear zones were reactivated in brittle-ductile to brittle regime with the kinematics of subhorizontal strikeslips (Jacko et al., 1996; Farkašovský, 2005, 2006; Jacko, 2007). During this stage the mylonites were penetrated by the subhorizontal stretching lineation of a NW-SE direction (Fig. 1C). The stretching lineation is a linking structural element of all mylonites in the area that retains constant orientation, irrespective of orientation or dip of the planar elements on which it occurs (Farkašovský, 2013).

The regional shear zones in the Veporicum of the Čierna hora Mts are the Roháčka, Slubica, Rolovská, Bujnisko and Margecany shear zones (Fig. 1A). Shear zones tectonically detach crystalline complexes of the Čierna hora Mts and now they are the dominant tectonic structures in the region (Fig. 1A). These mylonite zones have variable thicknesses of several metres to hundreds of metres. In most cases, borders of mylonite zones, as well as transitions of different types of tectonites to undeformed wall rocks, are not clear. The mineral associations of the mylonites indicate very low to low-grade metamorphic conditions of deformation (Korikovskij et al., 1989). The shear zones have a NW-SE direction and a medium dip to the southwest. The sole exception is the Rolovská shear zone and their mylonites which are subhorizontal eventually slightly inclined to the southeast (Fig. 1C). Mylonites along the Rolovská shear zone probably preserved the subhorizontal orientation of the original Hercynian foliation planes (Farkašovský, 2013).

The subject of our research was a 7-m-thick profile, tectonites of which belong to the broader area of the Rolovská shear zone (Fig. 1B). The Rolovská shear zone reactivates the contact of the Bujanová crystalline complex (ULU) in the south with the Lodina Complex (MLU) in the north (Jacko, 1975, 1979). Mylonites of gneisses, migmatites and granitoids are present in the region of the shear zone. The brittle-ductile tectonites form several tens of metres wide zone in the study area. The whole section studied is situated in mylonitised granitoid rocks of the Bujanová Complex. The outcrop forms the southwestern margin of the mylonites distribution at that locality. Undeformed or nearly undeformed granitoid rocks are present in the section, as well as different types of granitoid brittle-ductile tectonites from protomylonites to ultramylonites.

\section{Methodology}

The whole outcrop of the shear zone profile was first studied macroscopically in detail. The aim of that macroscopic study was to identify structurally different rocks with regard to their deformational reworking. Then places for oriented sample taking were selected (Fig. 1). The samples represented undeformed or only slightly deformed rocks as well as the different types of brittle-ductile tectonites - mylonites.

The mylonites in the section are rocks with strong foliation and well-marked traces of stretching lineation on the surface of the foliation planes. For the purpose of microscopic study, 25 oriented thin sections were prepared in the planes parallel to the stretching lineation and normal to the mylonitic foliation in order to characterise microfabric, deformational reworking, as well as mineralogical and modal composition of the tectonites. Microscopic observations were made using petrographic polarising microscope Olympus BX53.

The mylonites were classified according to metamorphic grade of deformation and to their original lithotype. Further, the mylonites were classified following the porphyroclasts/matrix ratio (Sibson, 1977). Mylonites with a matrix content of 10-50 per cent were classified as protomylonites, 50-90 per cent of matrix as mylonites (mesomylonites) and 90-100 per cent of matrix content as ultramylonites. The microfabric of the deformed rocks was assessed using Passchier and Trouw (1996).

Results of optical observations were compared with data from Röntgen (RTG) analyses. The powder X-ray diffraction analysis was chosen to be assessment tool for objective identification of the rock's mineral composition. It was useful especially in the case of very fine-grained rocks or of a less compact character, typical of the final mylonite products. The powdered samples were analysed using the Panalytical XPERT-PRO diffractometer. The goniometer P3064/60 was equipped with the distinction source with CoKa target $(1=0.1791 \mathrm{~nm})$ and Fe monochromatic filter. All scanned peaks angle positions $\left(10^{\circ}-120^{\circ} 2 q\right)$ in the recorded X-ray pattern were recalculated onto $\mathrm{d}_{\mathrm{m}}(\mathrm{nm})$ by a continuous batch program. The $\mathrm{d}_{\mathrm{t}} / \mathrm{I}_{\mathrm{t}}$ - diffraction lines were matched with the $\mathrm{d}_{\mathrm{m}} / \mathrm{I}_{\mathrm{m}}$ data of mineral standards with the internal data base or the selected diffraction data from the American Mineralogist Structure Data base (AMS). 
Bulk chemical composition analyses of representative brittle-ductile tectonites as well as undeformed rocks were determined in order to define chemical changes in rocks of the section. The bulk chemical composition (major, trace and rare earth elements) of samples from the Rolovská shear zone was analysed by ICP-Mass Spectrometry at ACME Analytical Laboratories Ltd., Vancouver, Canada, to evaluate possible chemical variability associated with the deformation gradient. Samples were collected at smaller intervals from the slightly deformed rock (samples 2, 3, 8, 9; Fig. 1B) through progressively more deformed samples (samples 4 , 5; Fig. 1B) into the highly-sheared ones (samples 6, 7; Fig. 1B). Their chemical composition was compared to the geochemistry of the undeformed precursor (biotite granodiorite, sample 1). The analyses are presented in Table 1.

\section{Structural and mineral composition changes in the Rolovská shear zone}

The whole section studied is situated in granitoid rocks of the Bujanová Complex and their tectonites (Fig. 1A, B). In the highest position of the section (sample 1) undeformed or only slightly deformed granitoid wall rocks occur. Lower in the section (samples 2 to 9) different tectonites of biotite granodiorite are present.

The macroscopically undeformed biotite granodiorite (sample 1) can have a slightly plane-parallel structure in the Čierna hora Mts. The texture is phaneritic granular (Fig. 2), the average size of the mineral grains reaching $1.5-3.5 \mathrm{~mm}$. On average, they contain 44 per cent of plagioclase, 26 per cent of quartz, 13 per cent of K-feldspar and 12 per cent of biotite that can be occasionally chloritised. In addition, muscovite, epidote and opaque minerals are

Table 1. Chemical composition of rocks (precursor-ultramylonite).

\begin{tabular}{|c|c|c|c|c|c|c|c|c|c|c|c|}
\hline Anal. & Unit & MDL & Sample 1 & Sample 2 & Sample 3 & Sample 4 & Sample 5 & Sample 6 & Sample 7 & Sample 8 & Sample 9 \\
\hline $\mathrm{SiO}_{2}$ & $\%$ & 0.01 & 65.68 & 66.36 & 65.20 & 73.89 & 75.65 & 90.96 & 91.83 & 64.43 & 64.23 \\
\hline $\mathrm{Al}_{2} \mathrm{O}_{3}$ & $\%$ & 0.01 & 15.84 & 15.85 & 15.92 & 16.03 & 14.16 & 4.38 & 4.46 & 15.68 & 16.29 \\
\hline $\mathrm{Fe}_{2} \mathrm{O}_{3}$ & $\%$ & 0.01 & 3.87 & 3.37 & 3.53 & 1.53 & 1.75 & 0.84 & 0.63 & 3.84 & 4.09 \\
\hline $\mathrm{MgO}$ & $\%$ & 0.01 & 1.41 & 1.31 & 1.34 & 0.6 & 0.61 & 0.28 & 0.27 & 1.66 & 1.58 \\
\hline $\mathrm{CaO}$ & $\%$ & 0.01 & 2.7 & 2.42 & 2.81 & 0.24 & 0.25 & 0.18 & 0.16 & 2.82 & 2.52 \\
\hline $\mathrm{Na}_{2} \mathrm{O}$ & $\%$ & 0.01 & 4.08 & 3.98 & 3.94 & 0.25 & 0.26 & 0.07 & 0.09 & 3.64 & 4.19 \\
\hline $\mathrm{K}_{2} \mathrm{O}$ & $\%$ & 0.01 & 3.01 & 2.38 & 2.59 & 4.58 & 4.42 & 1.39 & 1.36 & 2.73 & 2.81 \\
\hline $\mathrm{TiO}_{2}$ & $\%$ & 0.01 & 0.58 & 0.61 & 0.62 & 0.32 & 0.33 & 0.13 & 0.11 & 0.69 & 0.73 \\
\hline $\mathrm{P}_{2} \mathrm{O}_{5}$ & $\%$ & 0.01 & 0.247 & 0.24 & 0.26 & 0.14 & 0.13 & 0.08 & 0.06 & 0.27 & 0.29 \\
\hline $\mathrm{MnO}$ & $\%$ & 0.01 & 0.06 & 0.05 & 0.06 & 0.01 & $<0.01$ & 0.01 & $<0.01$ & 0.08 & 0.06 \\
\hline $\mathrm{Cr}_{2} \mathrm{O}_{3}$ & $\%$ & 0.002 & 0.004 & $<0.002$ & 0.002 & 0.002 & $<0.002$ & 0.002 & 0.003 & 0.004 & 0.003 \\
\hline $\mathrm{Ni}$ & ppm & 20 & 20 & $<20$ & $<20$ & $<20$ & $<20$ & $<20$ & $<20$ & $<20$ & $<20$ \\
\hline Sc & ppm & 1 & 7 & 7 & 7 & 4 & 4 & 1 & 1 & 8 & 8 \\
\hline LOI & $\%$ & -5.1 & 2.2 & 3.2 & 3.5 & 2.4 & 2.3 & 1.3 & 1.0 & 3.9 & 2.8 \\
\hline Sum & $\%$ & 0.01 & 99.7 & 99.79 & 99.79 & 99.99 & 99.84 & 99.62 & 99.99 & 99.77 & 99.56 \\
\hline $\mathrm{Ba}$ & ppm & 1 & 1323 & 730 & 732 & 756 & 778 & 125 & 136 & 847 & 2303 \\
\hline $\mathrm{Be}$ & ppm & 1 & 2 & 3 & 2 & 3 & 3 & 2 & 2 & 2 & 3 \\
\hline Co & ppm & 0.2 & 8 & 5.7 & 5.2 & 3.8 & 3.9 & 1.2 & 1.1 & 6.7 & 7.6 \\
\hline Cs & ppm & 0.1 & 3.1 & 3.9 & 4.8 & 4.5 & 4.7 & 1.3 & 1.3 & 3.9 & 5.0 \\
\hline $\mathrm{Ga}$ & ppm & 0.5 & 21.9 & 22.2 & 22.2 & 18 & 18.4 & 5.5 & 5.6 & 21.7 & 21.7 \\
\hline Hf & ppm & 0.1 & 7 & 7.1 & 5.4 & 4.9 & 5.0 & 1.2 & 1.3 & 7.7 & 8.0 \\
\hline $\mathrm{Nb}$ & ppm & 0.1 & 7.1 & 10.2 & 13.2 & 5.3 & 5.9 & 2.5 & 2.5 & 9.9 & 9.2 \\
\hline $\mathrm{Rb}$ & ppm & 0.1 & 74.5 & 87.6 & 94.5 & 156.3 & 149.8 & 49.5 & 48.2 & 98.5 & 98.2 \\
\hline Sn & ppm & 1 & 3 & 2 & 6 & 6 & 6 & 3 & 3 & 5 & 4 \\
\hline Sr & ppm & 0.5 & 674.7 & 411.9 & 365.8 & 65.1 & 68.9 & 22.2 & 21.8 & 353.7 & 618.5 \\
\hline $\mathrm{Ta}$ & ppm & 0.1 & 0.4 & 0.9 & 0.8 & 0.3 & 0.3 & 0.1 & $<1.1$ & 0.6 & 0.6 \\
\hline Th & ppm & 0.2 & 13 & 10.4 & 11.4 & 14.9 & 15.3 & 3.2 & 3.1 & 11.4 & 13.3 \\
\hline $\mathrm{U}$ & ppm & 0.1 & 2 & 1.9 & 2.0 & 1.4 & 1.5 & 0.6 & 0.6 & 2.1 & 1.9 \\
\hline V & ppm & 8 & 72 & 62 & 61 & 38 & 37 & 10.2 & 10 & 73 & 79 \\
\hline W & ppm & 0.5 & 0.5 & $<0.5$ & $<0.5$ & 19.5 & 19.5 & 1.3 & 1.3 & $<0.5$ & $<0.5$ \\
\hline $\mathrm{Zr}$ & ppm & 0.1 & 239 & 259.4 & 196.0 & 159.3 & 154.6 & 45.3 & 41.4 & 283.2 & 290.6 \\
\hline
\end{tabular}


present. Zircon, apatite, magnetite, titanite, allanite and \pm ilmenite occur as accessory minerals.

The feldspars are partially replaced by finegrained phyllosilicates. In slightly deformed rocks they can be deformed by brittle fracturing and in this case they are penetrated by sets of microfractures. Occasionally, the cracks or the spaces among mutually separated feldspar parts can be filled by secondary calcite. Deformation lamellae and undulose extinction are typical of quartz deformation. Microscopic movements along the 001 planes can be present in the micas.

Samples 2, 3, 8 and 9 represent structurally very similar brittle-ductile tectonites - protomylonites of biotite granodiorite (Fig. 3). The minerals that occur are plagioclase, quartz, orthoclase, biotite, muscovite, chlorite and calcite. Accessory minerals are epidote, zircon, apatite, magnetite, titanite and allanite. Microstructurally, mylonites are protomy- lonites with a matrix content of 35-50 per cent (Fig. 3). The matrix consists especially of small angular feldspar fragments, oriented white mica aggregates and smaller amounts of quartz and chlorite aggregates. The modal mineralogy of porphyroclasts, in the above-mentioned parts of the section, is also similar. The most abundant porphyroclasts are feldspars (23-30 per cent) and quartz (15-20 per cent). Minor constituents are micas, mainly biotite (8-11 per cent) and lesser muscovite (2-3 per cent). Average porphyroclast size is $0.1-3.0 \mathrm{~mm}$.

Feldspars are the major minerals in protomylonites. They are deformed in a brittle manner (Figs. 3d; 6A, B) and they cause the prevailing brittle deformation character of the tectonite on the microscopic scale. The feldspar porphyroclast size is visibly reduced with regard to the size of the original grains. They can occur in the form of larger, initially compact grains that are broken through

Table 1. cont.

\begin{tabular}{|c|c|c|c|c|c|c|c|c|c|c|c|}
\hline Anal. & Unit & MDL & Sample 1 & Sample 2 & Sample 3 & Sample 4 & Sample 5 & Sample 6 & Sample 7 & Sample 8 & Sample 9 \\
\hline$Y$ & ppm & 0.1 & 12.5 & 15.8 & 11.8 & 6.2 & 4.7 & 2.7 & 2.4 & 19.0 & 17.3 \\
\hline $\mathrm{La}$ & ppm & 0.1 & 48 & 40.9 & 43.6 & 48.1 & 45.2 & 17.8 & 15.9 & 55.6 & 60.7 \\
\hline $\mathrm{Ce}$ & ppm & 0.1 & 91.5 & 86.4 & 87.6 & 88.9 & 90.1 & 27.8 & 25.9 & 116.5 & 125.3 \\
\hline $\operatorname{Pr}$ & ppm & 0.02 & 10.08 & 9.46 & 10.46 & 10.83 & 10.39 & 2.70 & 2.88 & 12.51 & 13.69 \\
\hline $\mathrm{Nd}$ & ppm & 0.3 & 36.3 & 36.1 & 38.6 & 36.8 & 36.5 & 11.1 & 10.6 & 47.5 & 49.5 \\
\hline Sm & ppm & 0.05 & 5.08 & 5.67 & 6.21 & 4.59 & 4.88 & 1.51 & 1.45 & 6.95 & 7.37 \\
\hline $\mathrm{Eu}$ & ppm & 0.02 & 1.36 & 1.26 & 1.37 & 0.68 & 0.74 & 0.30 & 0.30 & 1.53 & 1.66 \\
\hline $\mathrm{Gd}$ & ppm & 0.05 & 2.79 & 3.59 & 4.32 & 2.29 & 2.38 & 0.87 & 0.97 & 4.19 & 4.57 \\
\hline $\mathrm{Tb}$ & ppm & 0.01 & 0.39 & 0.50 & 0.54 & 0.3 & 0.24 & 0.12 & 0.11 & 0.59 & 0.62 \\
\hline Dy & ppm & 0.05 & 1.82 & 2.37 & 2.39 & 1.05 & 1.07 & 0.48 & 0.50 & 2.90 & 2.83 \\
\hline Ho & ppm & 0.02 & 0.3 & 0.40 & 0.38 & 0.18 & 0.17 & 0.09 & 0.08 & 0.45 & 0.43 \\
\hline Er & ppm & 0.03 & 0.64 & 1.08 & 1.09 & 0.49 & 0.49 & 0.21 & 0.19 & 1.23 & 1.19 \\
\hline $\mathrm{Tm}$ & ppm & 0.01 & 0.11 & 0.16 & 0.19 & 0.07 & 0.08 & 0.03 & 0.03 & 0.19 & 0.18 \\
\hline $\mathrm{Yb}$ & ppm & 0.05 & 0.68 & 0.95 & 1.11 & 0.51 & 0.49 & 0.17 & 0.19 & 1.21 & 1.07 \\
\hline $\mathrm{Lu}$ & ppm & 0.01 & 0.11 & 0.15 & 0.17 & 0.08 & 0.08 & 0.03 & 0.03 & 0.17 & 0.16 \\
\hline TOT/C & $\%$ & 0.02 & 0.27 & 0.34 & 0.46 & 0.04 & 0.04 & 0.04 & 0.04 & 0.45 & 0.22 \\
\hline TOT/S & $\%$ & 0.02 & - & $<0.02$ & $<0.02$ & $<0.02$ & $<0.02$ & $<0.02$ & $<0.02$ & $<0.02$ & $<0.02$ \\
\hline Mo & $\%$ & 0.1 & 0.2 & $<0.1$ & 0.1 & 0.4 & 0.5 & 3.7 & 3.7 & $<0.1$ & $<0.1$ \\
\hline $\mathrm{Cu}$ & $\%$ & 0.1 & 7.8 & 6.4 & 3.4 & 11.2 & 11.4 & 13.0 & 13.1 & 22.0 & 14.8 \\
\hline $\mathrm{Pb}$ & $\%$ & 0.1 & 11 & 5.4 & 7.0 & 6.8 & 6.8 & 7.0 & 6.5 & 8.5 & 8.2 \\
\hline $\mathrm{Zn}$ & $\%$ & 1 & 84 & 48 & 46 & 7 & 7 & 12 & 12 & 32 & 64 \\
\hline $\mathrm{Ni}$ & $\%$ & 0.1 & 6.9 & 10.6 & 4.6 & 20 & 4.7 & 5.9 & 5.8 & 13.4 & 7.0 \\
\hline As & $\%$ & 0.5 & 1.1 & 0.9 & 1.4 & 6.2 & 6.3 & 1.4 & 1.5 & 2.0 & 1.6 \\
\hline $\mathrm{Cd}$ & $\%$ & 0.1 & 0.1 & $<0.1$ & 0.2 & 0.1 & 0.2 & 0.2 & 0.2 & $<0.1$ & $<0.1$ \\
\hline $\mathrm{Sb}$ & $\%$ & 0.1 & 1.2 & 0.3 & 0.1 & 0.5 & 0.6 & 0.5 & 0.5 & 0.4 & 0.4 \\
\hline $\mathrm{Bi}$ & $\%$ & 0.1 & 0.1 & $<0.1$ & $<0.1$ & 0.1 & 0.1 & 0.1 & 0.1 & 0.1 & $<0.1$ \\
\hline $\mathrm{Ag}$ & $\%$ & 0.1 & 0.1 & $<0.1$ & $<0.1$ & 0.1 & $<0.1$ & 0.1 & $<0.1$ & $<0.1$ & $<0.1$ \\
\hline $\mathrm{Au}$ & $\%$ & 0.5 & 0.5 & 6.0 & 6.7 & 10.0 & 10.3 & 8.5 & 8.6 & 0.7 & 3.2 \\
\hline $\mathrm{Hg}$ & $\%$ & 0.01 & 0.02 & 0.02 & 0.02 & 0.01 & $<0.01$ & 0.01 & $<0.01$ & 0.01 & 0.01 \\
\hline $\mathrm{Tl}$ & $\%$ & 0.1 & 0.2 & $<0.1$ & 0.1 & 0.1 & 0.1 & 0.1 & $<0.1$ & 0.1 & 0.3 \\
\hline Se & $\%$ & 0.5 & 0.5 & $<0.5$ & $<0.5$ & 0.5 & $<0.5$ & 0.5 & $<0.5$ & $<0.5$ & $<0.5$ \\
\hline
\end{tabular}



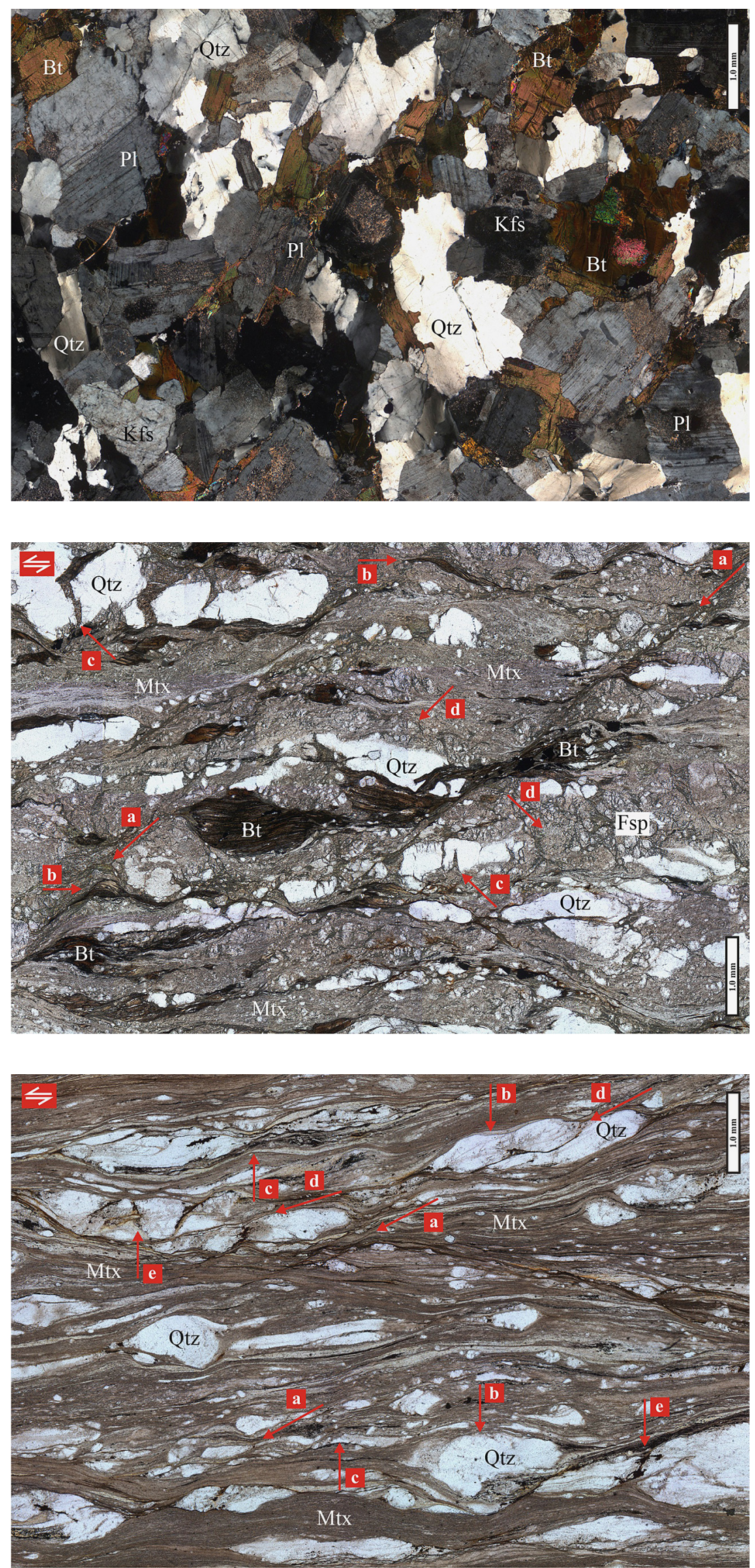

Fig. 2. Photomicrograph of the undeformed phaneritic granular biotite granodiorite composed mainly of plagioclase (Pl), quartz (Qtz), K-feldspar (Kfs) and biotite $(\mathrm{Bt})$. Scale $1 \mathrm{~mm}$. Crossed polarised light.

Fig. 3. Photomicrograph of the biotite granodiorite protomylonite (sample 2). The rock has a plane-parallel structure, contains porphyroclasts and matrix (Mtx). The porphyroclasts consist of quartz (Qtz), feldspars (Fsp) and biotite (Bt). Characteristic microstructures are penetrative, relatively straight shear bands (a); asymmetrical mica fish formed mainly by biotite (b); brittle fragmentation of quartz (c) and feldspar (d) grains. Sinistral shear sense. Scale $1 \mathrm{~mm}$. Plane polarised light.

Fig. 4. Photomicrograph of the biotite granodiorite mesomylonite (sample 5). The rock has a strong plane-parallel structure and mylonitic texture with abundant quartz porphyroclasts (Qtz) and aphaninic matrix (Mtx). Common microstructures are short shear bands (a), asymmetrical quartz porphyroclasts (b), ductile bending of the longitudinal quartz grains and matrix mineral aggregates (c), synthetic microfaults in quartz porphyroclasts (d), fragmentation of larger quartz grains (e). Sinistral shear sense. Scale 1 $\mathrm{mm}$. Plane polarised light. 
sets of fractures. Generally, fractures are straight cleavage planes of feldspars and they are filled by white mica aggregates (Fig. 6A, B). The small angular feldspar fragments are more often separated from original mineral grains and enclosed in the matrix of the protomylonite. The size of quartz porphyroclasts in the protomylonite is comparable to that of undeformed rock mineral grains. Typical microstructures of quartz are deformation lamellae, undulose extinction and brittle fractures (c in Fig. 3). 001 cleavage planes plastic bending and mica fish microstructures (b in Fig. 3) are characteristic of dark micas. The shear bands are typical microstructures of the protomylonite (a in Fig. 3). They include $40-45^{\circ}$ angles to macroscopically dominant foliation planes. The shear bands are short and are present locally rather than penetrative. Typical ductile bending of the oriented white mica and quartz matrix aggregates occurs near the shear bands. In terms of rock deformation, aggregates of the secondary calcite in the quartz grains brittle fractures or in the spaces among boudinaged quartz grains are important. The carbonate mineralisation can fill spaces among separated feldspar parts or can be present locally along the shear bands.

Samples 4 and 5 consist of mylonites of biotite granodiorite (Fig. 4). The major rock-forming min- erals are quartz and muscovite. Accessory minerals are chlorite, biotite, zircon and \pm ilmenite. On a microscale the tectonite can be classified as mesomylonite with a matrix content of 72-77 per cent. The matrix is formed mainly by oriented white mica aggregates, oriented aggregates of dynamically recrystallised quartz and, to a lesser extent, by chlorite aggregates. The porphyroclasts are mainly quartz (23 per cent) and muscovite ( 3 per cent). The size of the porphyroclasts varies between $0.1-2.5$ $\mathrm{mm}$.

The deformational microfabric in the mylonite has a predominantly ductile character. The feldspars, brittle-deformed in the protomylonites, were completely reduced in mesomylonites during deformation. The quartz porphyroclasts (b in Fig. 4) are markedly elongated parallel to the stretching lineation direction and parallel to foliation planes. The borders of quartz porphyroclasts are recrystallised to subgrains in the direction of their elongation. Also tails of dynamically recrystallised quartz and opaque minerals extend onto the sides of the porphyroclasts, parallel to the shape fabric of the mylonite. Larger quartz grains with strong undulose extinction and sometimes with deformation lamellae can either be transected by microfaults ( $d$ in Fig. 4; 6C) or fragmented (e in Fig. 4). Muscovite



Fig. 5. Photomicrograph of the biotite granodiorite ultramylonite (sample 7). The rock has a strong plane-parallel structure and aphanitic texture. The mylonite is formed mainly by the matrix (Mtx) and by a small amount of quartz porphyroclasts (Qtz). Usual microstructures are longitudinal porphyroclasts of quartz oriented parallel to mylonite foliation, occasionally with visible shape asymmetry (a). Trails of small quartz grains extend laterally from the tips of porphyroclasts (b). Ultramylonite disrupted by a narrow quartz vein (c). Scale $1 \mathrm{~mm}$. Polarisers at $45^{\circ}$. Crossed polarised light. 
porphyroclasts are rarely present in the form of the mica fish. The asymmetric microstructures of the short shear bands occur rather locally and they are not penetrative (a in Fig. 4). They form an angle of $40-45^{\circ}$ to the main foliation of the mylonite. The quartz and mica porphyroclasts, as well as oriented mineral aggregates of the matrix, are bent near the shear bands (c in Figs. 4; 6C).

Samples 6 and 7 comprise ultramylonites of biotite granodiorite (Fig. 5). The major rock-forming minerals are quartz and muscovite, while accessories are orthoclase, biotite, chlorite, calcite and opaque minerals. In term of microstructure, ultramylonites have a matrix content of 90-95 per cent (Fig. 5). The matrix consists of oriented aggregates
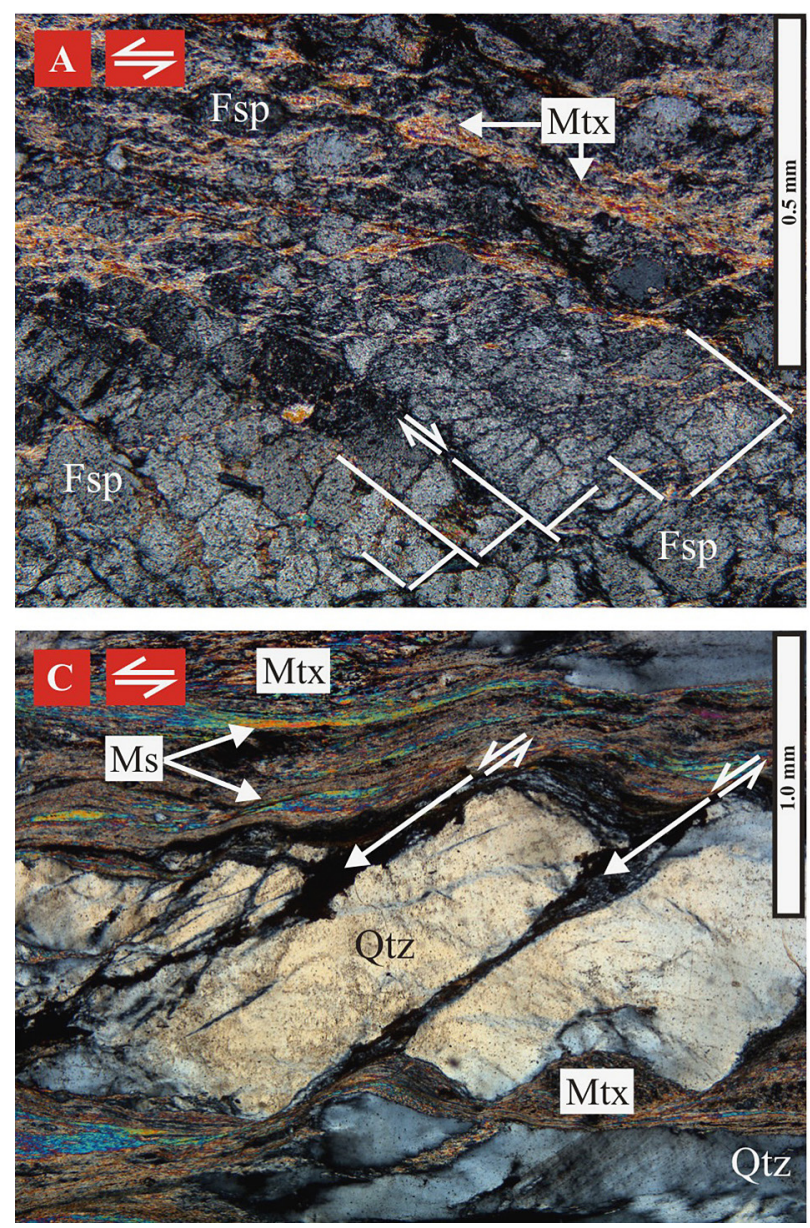

of both dynamically recrystallised quartz and of white mica and chlorite. The porphyroclasts consist mainly of quartz (8 per cent) and, to a lesser extent, of muscovite ( 1 per cent). Their size varies between 0.05-1.3 mm.

The tectonite microstructure in the most deformed part of the shear zone is limited by a high matrix content (Fig. 5) that is closely connected with high rock silicification. The quartz porphyroclasts are elongated parallel to stretching lineation and foliation. They can be disintegrated by irregular fractures (Fig. 6D). The quartz cores of the porphyroclasts show strong undulose extinction (a in Fig. 5). The fine-grained quartz, mica and opaque mineral aggregates extend laterally from the tips of
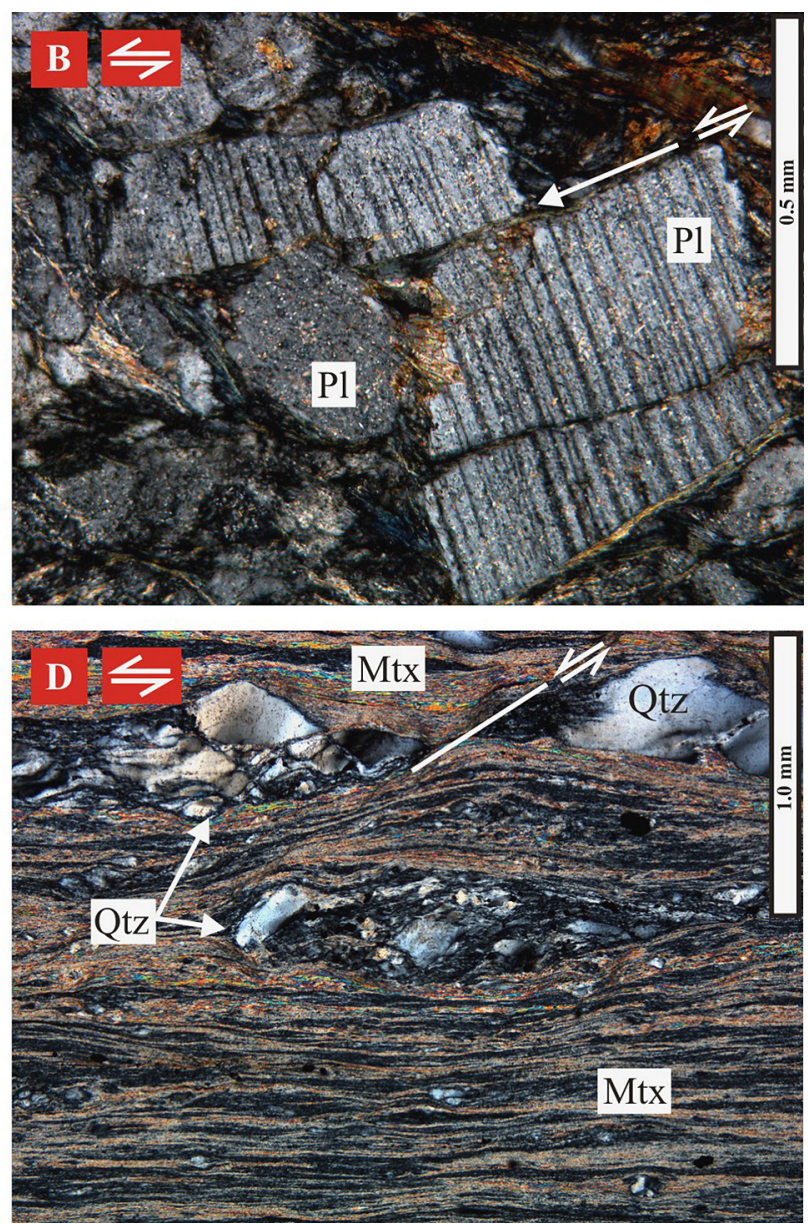

Fig. 6. Feldspars transected by irregular fractures or by sets of relatively straight microfaults in protomylonites (A - sample 3; B - sample 8). The relative movement of rigid mineral fragments can be antithetic (A) or synthetic (B), concerning bulk shear sense in the mylonite. Gradual increase of sericite aggregates among separated feldspar fragments can be observed in the protomylonite (A). Porphyroclasts of quartz in the mesomylonite and ultramylonite behave as rigid mineral grains in a relatively less competent matrix ( $\mathrm{C}$ - sample 5; D - sample 6). Quartz grains show undulose extinction (C, D) and occasionally deformation lamellae (C, lower right). Larger porhyroclasts of quartz may be transected by straight microfaults with synthetic relative displacement of the fragments (C). Mineral aggregates of matrix, as well as elongated muscovite grains, are plastically bent near the competent grains. Quartz porphyroclasts are disintegrated mostly by irregular fractures in the ultramylonite (D). Mutual displacement of adjacent quartz grains can be observed (D). Sinistral shear sense. Polarisers at $45^{\circ}$. Crossed polarised light. 
porphyroclasts (b in Fig. 5). Material flanking porphyroclast cores can assume asymmetrical shapes. Muscovite porphyroclasts are present only rarely. Unlike other brittle-ductile tectonites of the section studied these tectonites do not contain shear bands. The ultramylonites are disrupted by narrow quartz veins with sharp boundaries (c in Fig. 5).

\section{Chemical changes of tectonites in the shear zone section}

The Rolovská shear zone tectonites represent a deformed analogue of the granitoid rocks of the Čierna hora crystalline basement. The chemical compositional difference among the various types of mylonites and their precursors (undeformed to
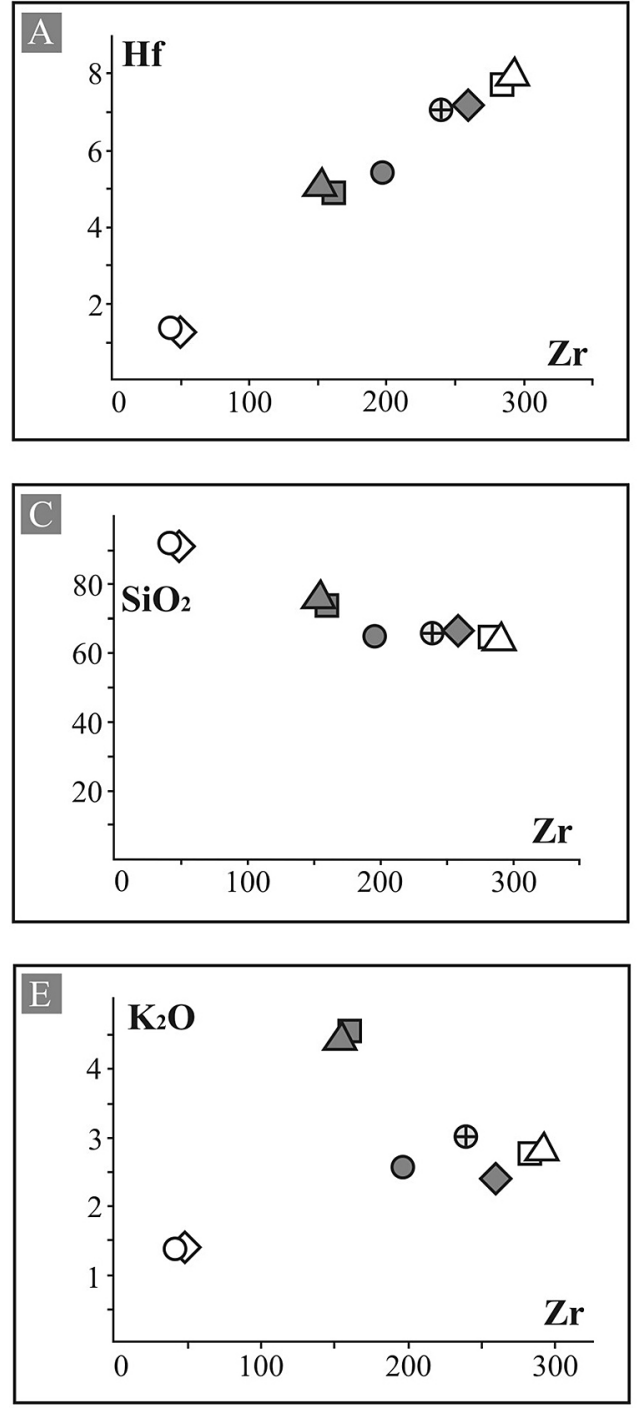

only slightly deformed biotite granodiorite) is indicative of certain chemical changes during deformation. Distribution changes of major, trace and rare earth elements can be seen in Figures 7-10. The result of deformation and related geochemical changes is a recrystallisation of the original minerals and the formation of new ones.

To assess the chemical changes of the different shear zone profile tectonites, it is assumed that $\mathrm{Zr}$ belongs to the more or less immobile elements under metasomatic conditions (Ague, 1994; Baumgartner \& Olsen, 1995; Steyrer \& Sturm, 2002; Arancibia $\&$ Morata, 2005). This assumption enables to verify mobility or immobility of chemical elements using variation diagrams (Fig. 7). The elements that indicate an immobile character show good correlation with $\mathrm{Zr}$, whereas mobile elements would plot outside a theoretical correlation line (Fig. 7). The ele-
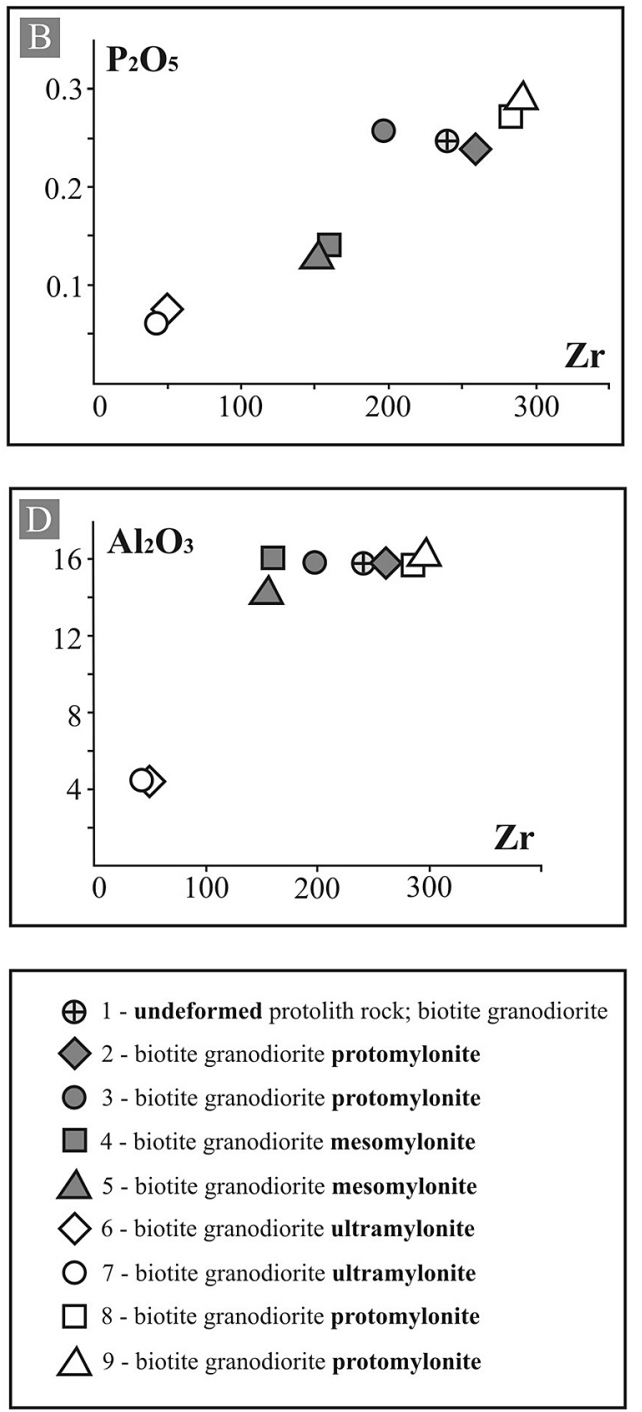

Fig. 7. Variation diagrams of some trace (in ppm) and major (in wt.\%) elements with respect to $\mathrm{Zr}$ for mylonites of the Rolová shear zone. A - Zr vs Hf; $\mathbf{B}-\mathrm{Zr}$ vs $\mathrm{P}_{2} \mathrm{O}_{5} ; \mathrm{C}-\mathrm{Zr}$ vs $\mathrm{SiO}_{2} ; \mathrm{D}-\mathrm{Zr}$ vs $\mathrm{Al}_{2} \mathrm{O}_{3} ; \mathbf{E}-\mathrm{Zr}$ vs $\mathrm{K}_{2} \mathrm{O}$. 
ments distributed out of the theoretical correlation line would have gained or lost by the system, respectively (Arancibia \& Morata, 2005). To evaluate element mobility or immobility it is necessary to assume that (1) the fault rock and wall rock originated from the same protolith, (2) the protolith had a relatively homogeneous composition of chemical elements, (3) density variations for the transition of the fault rock to the wall rock are not significant (Ague, 1994; Ague \& van Haren, 1996; Grant, 2005). Following the above-mentioned facts, it can be observed that $\mathrm{Zr}$, Hf and $\mathrm{P}$ (Fig. 7) represent immobile elements or elements with very low mobility. In contrast, $\mathrm{Si}$ and $\mathrm{K}$ appear to be mobile elements. The concentration of Al relative to $\mathrm{Zr}$ remained unchanged during the alteration processes (except for the ultramylonite, Fig. 7D).

Moreover, relative changes in whole-rock element concentrations between the unaltered protolith and the sheared rocks can be graphically evaluated using of the Isocon method (Grant, 1986, 2005). The selected major and trace element concentrations (multiplied by different scaling factors) are projected in the diagram as protolith vs different mylonite types (Fig. 8). Those elements that lie on a straight line passing through the origin of the diagram are defined as isocons (Grant, 1986, 2005; Arancibia \& Morata, 2005). Ideally, the points for which constituents remained unchanged during the hypothetical isochemical metamorphism, lie on a constant mass line. The straight isocon line is drawn from the origin in the best-fit manner through data points for constituents that are normally immobile in fluid-rich systems. Because relatively immobile elements or elements distributed along the isocon usually are considered Zr, Ti and P (Grant, 1986, 2005), perhaps even Al (Moore et al., 1970; Ague, 1991; Condie \& Sinha, 1996; Johnson et al., 2008 and others). Isocon diagrams show mass-conservative processes in protomylonite samples (Fig. 8A, B, G, $\mathrm{H})$, i.e., immobile elements ( $\mathrm{Al}, \mathrm{P}, \mathrm{Ti})$ plot along the mass-conservative isocon the slope of which is 1 . It is worth mentioning that $\mathrm{Pb}, \mathrm{Zn}, \mathrm{Sr}$ and, in part $\mathrm{Ba}$, show a quite consistent behaviour in protomylonites. They are always depleted in protomylonites in comparison to the protolith (except for Ba in sample 9).

In more deformed rocks of the section studied the isocon through $\mathrm{Zr}, \mathrm{Ti}, \mathrm{P}$ (and Hf) is consistent with suspected major and trace element gains $\left(\mathrm{SiO}_{2}\right.$, $\left.\mathrm{K}_{2} \mathrm{O}, \mathrm{Rb}\right)$ and losses $\left(\mathrm{Na}_{2} \mathrm{O}, \mathrm{MgO}, \mathrm{Fe}_{2} \mathrm{O}_{3}, \mathrm{Sr},+/-\mathrm{Ba}\right)$ based on chemical data (Fig. 8). Obvious chemical changes occur in mesomylonites (Fig. 1, samples 4 and 5) and ultramylonites (Fig. 1, samples 6 and $7)$. The content of $\mathrm{K}$ and $\mathrm{Rb}$ considerably increases whereas an evident depletion occurred in the case of $\mathrm{Fe}, \mathrm{Na}, \mathrm{Ca}$ and $\mathrm{Sr}$ in mesomylonites (Fig. 8C, D). The significant increase in Si content is characteristic of ultramylonite (Table 1; Fig. 8E, F) associated with whole-rock silicification along with a smaller phyllosilicate volume. The content of Fe, $(+/-\mathrm{Mg})$, $\mathrm{Sr}, \mathrm{Ca}, \mathrm{Ba}$ and $\mathrm{Na}$ commonly decreases due to dark mica and plagioclase breakdown and recrystallisation. Notably Sr and, in part, Ba trace elements drop is an expression of the reduction of plagioclase content. Rb shows a gain. $\mathrm{Mg}$ and Fe concentrations gradually decrease from the precursor via protomylonite to ultramylonite indicating dark mica and newly formed chlorite content changes. Their content near the isocon in the ultramylonite signals lateral migration within the mylonite zone rather than addition to the system (Hippertt, 1998). Generally, all changes in major oxide abundances reflecting the modal changes attend the process of mylonitisation. The isocon of the ultramylonite (Fig. 8E, F), as defined by the immobile element positions $(\mathrm{Zr}, \mathrm{Ti}$ and $\mathrm{P}$ ), assumes a volume gain for silica. Silica was added, so its concentration increased from $65.68 \mathrm{wt}$. per cent in the protolith to $91.83 \mathrm{wt}$. per cent in the ultramylonite.

Rare earth elements (REE) generally are insoluble in aqueous fluids, so they are useful as petrogenetic indicators in altered rocks. The REE behaviour can be observed in the normalised multi-element diagram (Fig. 9). In the diagram the normalised concentrations of REEs (y-axis) are plotted against elements with increasing atomic number (x-axis). Light rare earth elements (LREE) show a rather immobile behaviour in protomylonites to mesomylonites. Heavy rare earth elements (HREE) are slightly enriched in protomylonites and on the other hand, their content in mesomylonites slightly decreases. The content of all REEs decreases in ultramylonite. In the case of mesomylonites and, in part, ultramylonites Eu shows a slightly negative anomaly that can relate to feldspar destruction and its alteration during deformation.

To differentiate between volume-gain, isovolume or volume-loss conditions of shear deformation the discrimination criteria of Condie and Sinha (1996) were used. Normalised mylonite/ protolith oxide ratios $\left(\mathrm{SiO}_{2}\right.$ vs $\mathrm{Na}_{2} \mathrm{O}$ and $\mathrm{TiO}_{2}$ vs $\mathrm{Al}_{2} \mathrm{O}_{3}$ ) allow to discriminate between volume-gain or volume-loss mylonitisation processes (Fig. 10). According to these criteria the mesomylonites and ultramylonites of the Rolovská shear zone belong to the isovolume/volume gain category of high-strain shear zones (Fig. 10) which is consistent with results obtained from isocon diagrams (Fig. 8). The increasing $\mathrm{SiO}_{2}$ with deformation in this shear zone seems 

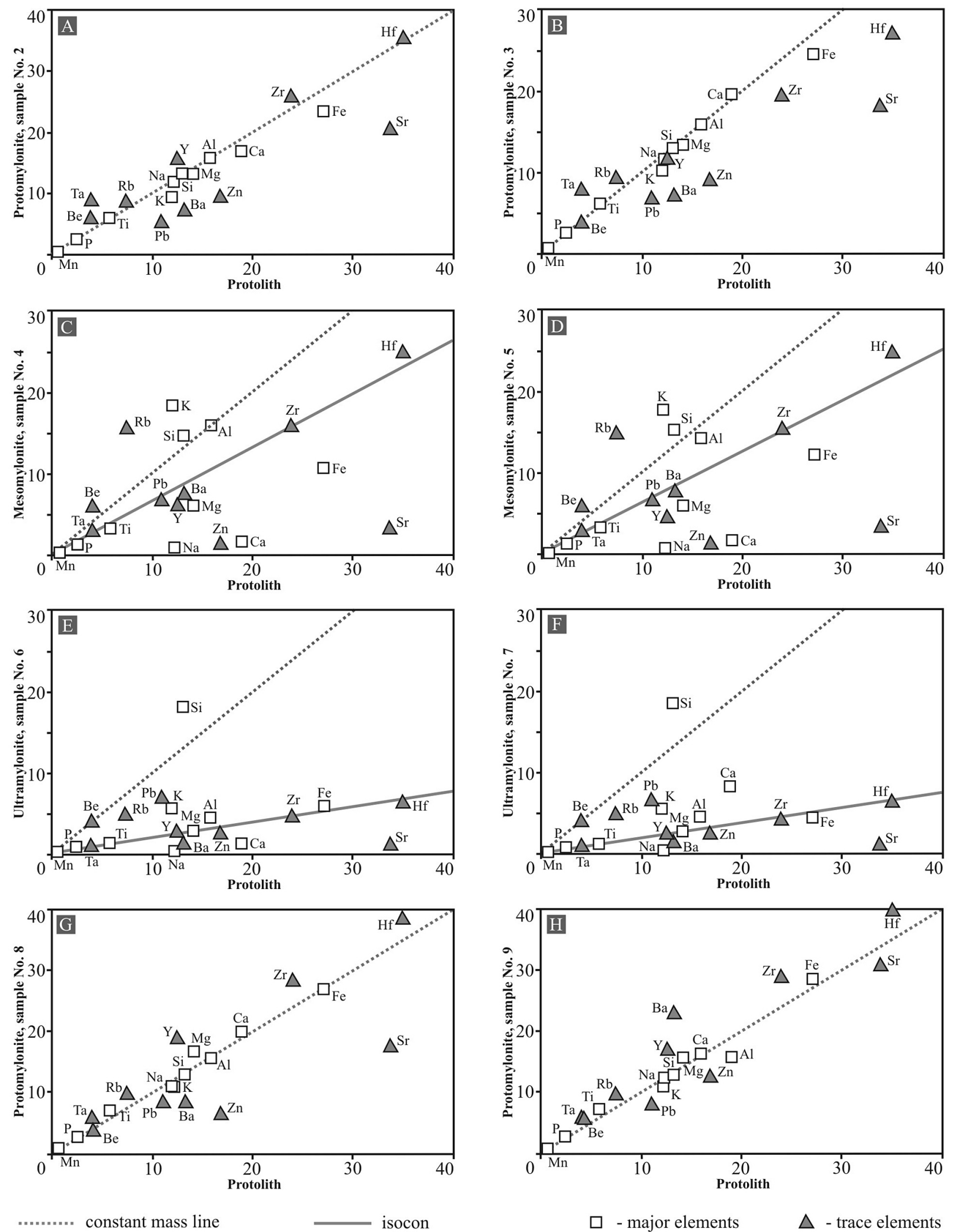

Fig. 8. Plots of element concentration in the precursor (biotite granodiorite) vs concentration in the mylonites from different subzones (multiplied by scaling factors). Concentrations of major elements are plotted in wt. percentage and trace elements in ppm. Scaling factors used to plot elements were: 0.01 for $\mathrm{Ba}, 0.05$ for $\mathrm{Sr}, 0.1$ for $\mathrm{Zr}$ and $\mathrm{Rb}, 0.2$ for $\mathrm{Zn}$ and $\mathrm{SiO}_{2}, 1$ for $\mathrm{Y}, \mathrm{Pb}, \mathrm{Al}_{2} \mathrm{O}_{3}, 2$ for $\mathrm{Be}, 3$ for $\mathrm{Na}_{2} \mathrm{O}, 4$ for $\mathrm{K}_{2} \mathrm{O}, 7$ for $\mathrm{Fe}_{2} \mathrm{O}_{3}$ and $\mathrm{CaO}, 10$ for $\mathrm{MgO}, \mathrm{TiO}_{2}, \mathrm{P}_{2} \mathrm{O}_{5}, \mathrm{Cr}_{2} \mathrm{O}_{3}$ and Ta. 


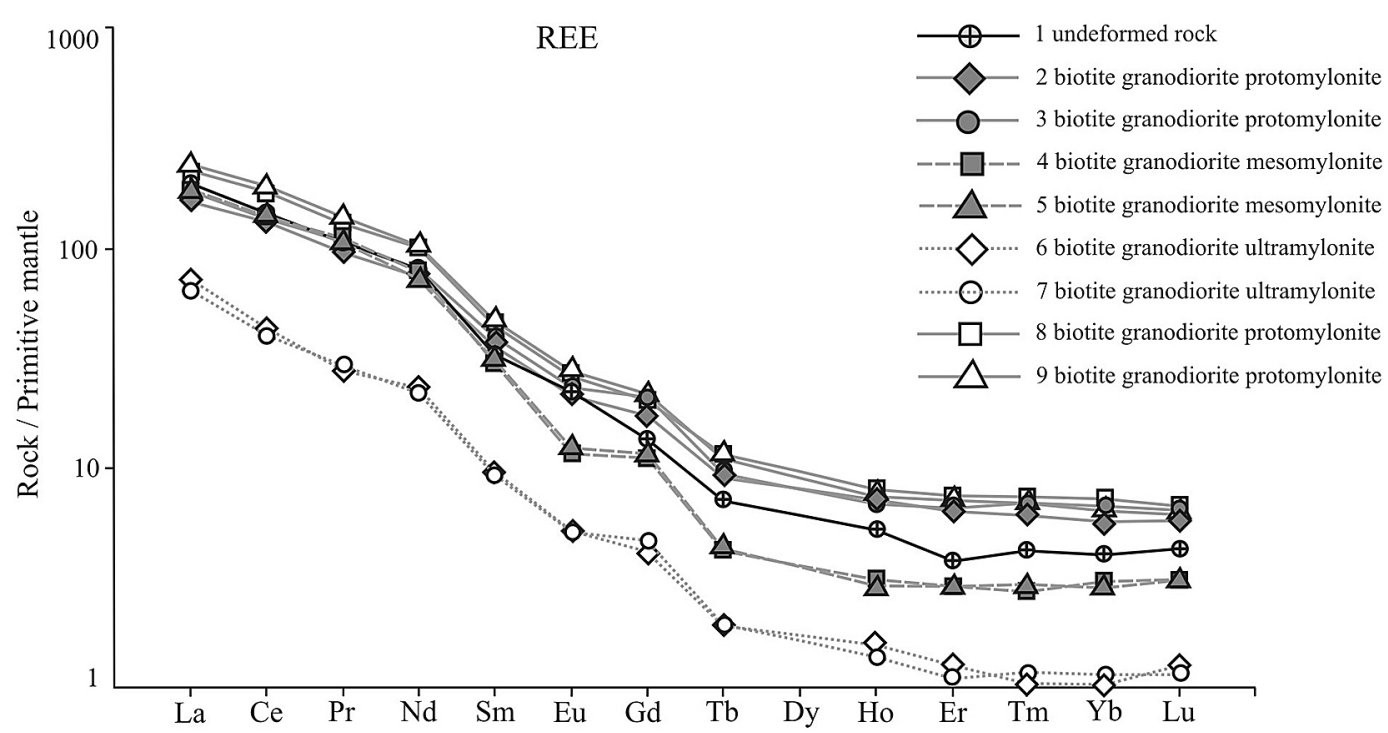

Fig. 9. Diagram of chondrite-normalised contents of REE (Evensen et al., 1978) in the rocks studied.
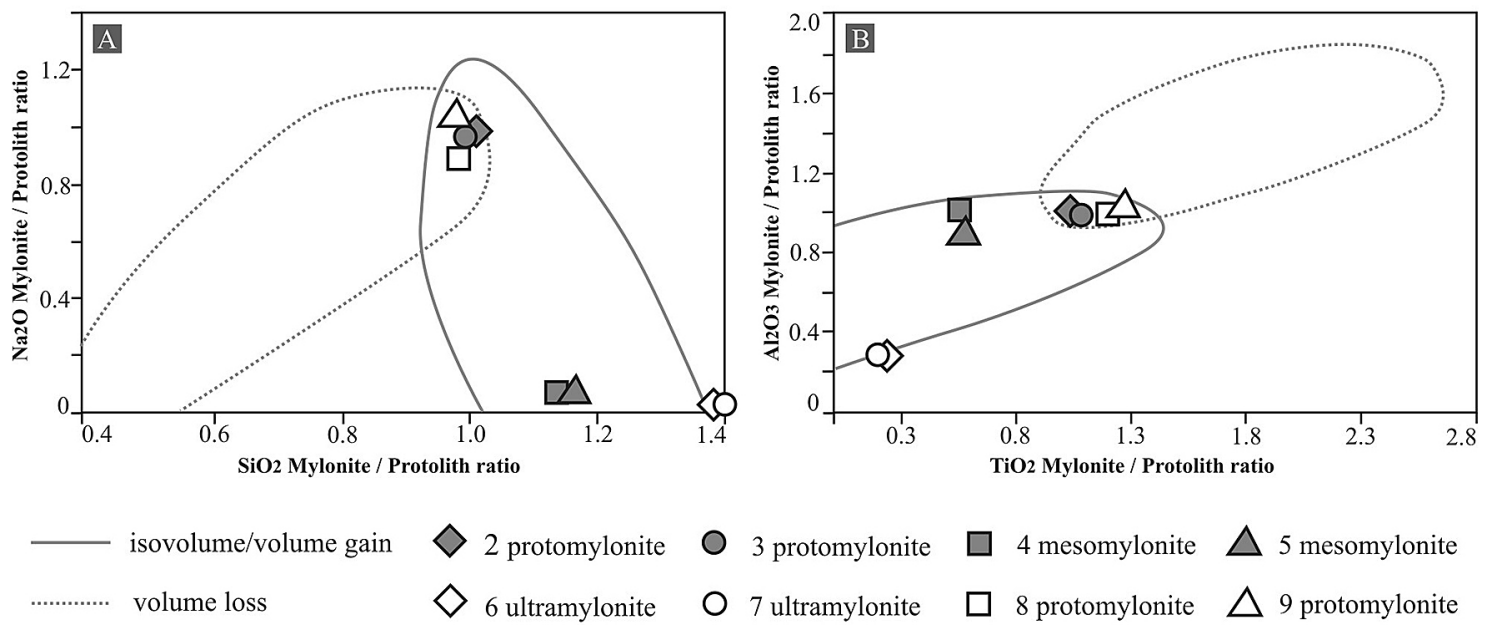
3 protomylonite
7 ultramylonite

4 mesomylonite

$\triangle 5$ mesomylonite

8 protomylonite

$\triangle 9$ protomylonite

Fig. 10. Plot of the concentration ratio of mylonite/protolith: $\mathbf{A}-\mathrm{Na}_{2} \mathrm{O}$ and $\mathrm{SiO}_{2} ; \mathbf{B}-\mathrm{TiO}_{2}$ and $\mathrm{Al}_{2} \mathrm{O}_{3}$ in deformed granitoids from the Rolovská shear zone (Condie \& Sinha, 1996).

to reflect the introduction of quartz. The projection points of the protomylonites in which volume changes are not assumed, concentrate in the intersections of the volume-gain and volume-loss fields.

\section{Discussion}

Mylonite zones, as typical structural features of Veporic unit, developed during several deformational stages of the Alpine orogeny in the Čierna hora Mts (Jacko et al., 2001; Jacko, 2007). The process of mylonitisation in the west of the Veporicum was also polystage. Kohút et al. (2000) described two tectonic events: the older high-pressure progressive deformation related to maximum burial and an overlapped retrograde younger event dur- ing rapid uplift of the crystalline complex. Two different stages of mineral and chemical changes with increasing deformation were observed by Putiš et al. (1997) in the Vepor pluton near the Pohorelá thrust (Veporicum).

The deformation during the Alpine orogeny in the Čierna hora Mts reached green schist facies metamorphic conditions (Jacko, 2007), which coincides with observations from the western part. Putiš et al. (1997) identified Alpine mylonitisation of the Vepor pluton granitoid suite in Bt and Bt-Grt conditions of the greenschist facies. Consequently, deformation of the minerals with different rheology in the various mylonite types of the section studied corresponds to this. Deformation of minerals was observed especially on larger rock grains or on porphyroclasts. The feldspars in the rocks of the section are invari- 
ably deformed in a brittle manner, forming a hard phase ( $\mathrm{d}$ in Fig. 3). Typically they are transected by sets of brittle fractures. Synthetic as well as antithetic microfaults are present in the feldspar grains (Fig. $6 \mathrm{~A}, \mathrm{~B})$. Internal brittle fracturing and deformation lamellae formation is characteristic of feldspars at temperatures of $300-400{ }^{\circ} \mathrm{C}$ (Pryer, 1993). At temperatures of $400-500{ }^{\circ} \mathrm{C}$ recrystallisation of feldspar grains starts along their edges, but porphyroclasts may still be fractured (Pryer, 1993). In the granodiorite mylonites studied, recrystallisation of feldspars was not observed. Quartz porphyroclasts in the protomylonites are brittle deformed (c in Fig. 3). Quartz in mesomylonites forms a weak phase with a predominant plastic character of deformation (Fig. 4 ). Ductile bending of single grains or quartz aggregates is common near the shear bands or at contacts with the rheologically more competent grains (Fig. 4c). Strong undulose extinction (Figs. 2; 5a; 6C, D) or lesser deformation lamellae (Fig. 6C) are typical of quartz grains. In the mylonites with a higher matrix content quartz porphyroclasts can show brittle deformation (Figs. 4e; 5; 6C, D). This feature was observed also by Putiš et al. (1997) in ultramylonites in which quartz porhyroclasts behaved as the hard phase in the newly formed muscovite-phengite and biotite matrix aggregates. Mica porphyroclasts, formed especially by biotite, are present in protomylonites (Fig. 3). They are deformed plastically. The mica fish microstructures (ten Grotenhuis et al., 2003), slides on the 001 crystallographic planes and ductile bending near the shear bands are common (b in Fig. 3).

Mineral grainsize gradually decreases from the borders of the shear zone towards to the centre (Figs 2-5). Typical grainsize reduction connected with deformation was described also by Putiš et al. (1997) and Kohút et al. (2000) from the western parts of the Veporicum. It can be observed that grainsize reduction relates to an increase of deformational reworking and strain softening of the rock. Reduction of the mineral grainsize is linked also to the successive matrix volume increase, considering porphyroclast content. The size of the single mineral grains in the oriented matrix aggregates is $<0.05 \mathrm{~mm}$. The average grainsize in the undeformed granitoids reaches $3.0 \mathrm{~mm}$. Initial grainsize reduction can be accomplished by the rock cataclasis. The original rock fabric is destroyed, which results in a more homogeneous distribution of mineral phases (Goodwin \& Wenk, 1995). Brittle breakdown of the feldspars causes mineral grain reduction already in the protomylonites. The size of the quartz porphyroclasts is strongly reduced normal to the foliation and stretched parallel to the foliation planes in mesomylonites and ultramylonites. The quartz content in the mylonite decreases markedly as well.

The matrix of the mylonite is formed by mineral grains that are smaller than grains of porphyroclasts (Passchier \& Trouw, 1996). Mylonite matrix usually is recrystallised but in low-grade mylonites a considerable part of matrix is not necessarily the product of recrystallisation (Trouw et al., 2010). In this sense the matrix is a structurally more finegrained compound of the mylonite. The limit of grainsize between matrix and porphyroclasts is variable, depending on the microstructural character of mylonite. The protomylonite matrix (Fig. 3 ) is composed mainly of small-sized angular feldspar fragments and oriented aggregates of quartz, white mica or chlorite. The mesomylonite and ultramylonite matrix (Figs. 4, 5) are formed especially by oriented aggregates of dynamically recrystallised quartz, oriented aggregates of white mica and chlorite. Feldspar fragments occur very rarely. The composition and structure of matrix changes in the frame of the shear zone section. The content of small angular feldspar fragments decreases towards more deformed mylonites. They are substituted successively by oriented aggregates of white mica. The content of oriented quartz aggregates increases markedly in the matrix of mesomylonites and especially in ultramylonites. This fact is manifested by the strong tectonite silicification in the centre of the shear zone. The $\mathrm{SiO}_{2}$ content reaches almost $92 \%$ in ultramylonites (Table 1). A matrix comprised of fine-grained quartzo-feldspatic layers and fine-grained muscovite-sericite interlayers was described also by Kohút et al. (2000) from granitoid mylonites of the western part of the Veporicum.

In the mylonites studied the variety of microstructures formed due to the effects of cataclasis, ductile deformation and recrystallisation of the original mineral assemblage. The macroscopically undeformed granitoid rocks from the border of the shear zone studied contain a network of grain boundary and transgranular brittle fractures on a microscale. The mylonites can progressively develop by plastic reactivation of these brittle precursors during greenschist facies metamorphic conditions (Guermani \& Pennacchioni, 1998). The predominant feature of the mylonites studied is their foliation. In the protomylonites sets of brittle shear bands (a in Fig. 3) are developed that are not parallel to the shear zone boundaries (Berthé et al., 1979; Platt \& Vissers, 1980; Platt, 1984; Passchier \& Trouw, 1996). S-C fabrics similar to those of mylonites can develop already in cataclastic granitoid rocks (Lin, 1999). In mylonites with a high matrix content the predominant foliation is parallel to the 
shear zone boundary (Figs. 4, 5). In mesomylonites shear bands oblique to the shear zone boundary are only less developed (a in Fig. 4). In ultramylonites, shear bands disappear completely (Fig. 5), which coincides with the observation by Kohút et al. (2000). In the western part of the Veporic unit, as kinematic indicators the S-C planes (Lister \& Snoke, 1984), asymmetrical porphyroclasts and microfaults were recognised (Putiš et al., 1997).

The deformation processes in the frame of mylonite zone analysed led to specific allochemical changes. The transition from undeformed granodiorite rock to protomylonite does not show substantial chemical changes in major elements (Table 1). However, there is a distinct change for $\mathrm{Pb}, \mathrm{Ba}$, $\mathrm{Zn}$ and $\mathrm{Sr}$ contents (Fig. 8). These trace elements are depleted in all protomylonite samples. Sr decline (and, in part, $\mathrm{Ba}, \mathrm{Pb}$ concentration) indicates a beginning removal of feldspar and eventually its breakdown. Decrease of $\mathrm{Zn}$ probably is the result of biotite and/or magnetite decrease which usually concentrates the trace element mentioned. This phenomenon is also manifested in a slight decrease in Fe. The difference in the whole chemical composition is visible mainly between protomylonites and mesomylonites as well as between mesomylonites and ultramylonites (Table 1, Fig. 8) which contrasts with the investigations carried out by Kamenický (1977). According to Kamenický no essential change in chemical composition was recognised from the undeformed granitoid rocks up to the final stage of the alteration represented by ultramylonites in the Čierna hora crystalline basement. During mylonitisation, the original biotite granodiorite was depleted of magnesium, iron, sodium, calcium and barium. In contrast, potassium and rubidium and mainly silica considerably increased. Other (major and trace) elements reflect an erratic behaviour due to lateral mobility. Chemical changes indicate a breakdown and subsequent recrystallisation of biotite and feldspars as well as crystallisation of albite and sericite. Certain allochemical changes in granitoid rocks due to cataclasis, pressure solution and recrystallisation were observed also by Putiš et al. (1997) and Kohút et al. (2000) in the western part of the Veporic crystalline basement.

Oriented aggregates of white mica form an important component in the mylonite matrix. Sericitisation of the feldspars or new muscovite (white mica) formation is possible only under metamorphic conditions abundant in fluids. The white mica precipitates in the shear zone conditions simultaneously with alkali feldspar (orthoclase, albite) destruction. Orthoclase is a common constituent of the undeformed rock precursor and in relative- ly lesser amount is also present in its mylonitised equivalents. Possible changes of the plagioclase of oligoclase and andesine composition that is common in the granodiorite protolith (Bónová, 2006), are related to a decrease of Ca content and its transformation to albite. The sericitisation of plagioclase and partial reduction of K-feldspar continue up to complete consumation of plagioclase in the most deformed rocks. A drop in $\mathrm{Ca}, \mathrm{Na}$ and $\mathrm{Sr}$ concentrations is evident. These observations are in accordance with feldspar destruction and its absence in the most deformed parts of the shear zone. The white mica content increase in the mesomylonite and ultramylonite of the most deformed parts of the section compared to protomylonite reflected a similar behaviour of $\mathrm{Rb}$ and $\mathrm{K}$. A relative decrease of $\mathrm{K}_{2} \mathrm{O}$ content in the ultramylonite compared to mesomylonite is probably due to continuous mica development accompanied by breakdown of the alkali feldspar. Indeed, following the isocon diagram (Fig. 8C-F) concentration of potassium shows a rise. The released Ca may be partly consumed in the formation of epidote, calcite and/or secondary titanite. Nevertheless, epidote is quite rare in the rocks studied (sample 9), yet calcite is frequent. Ca can be partially consumed during white mica generation (Hippertt, 1998; Hippertt \& Hongn, 1998). Dissolution of quartz and feldspars enhances $\mathrm{Al}$ and $\mathrm{Si}$ activity that participate in white mica precipitation.

Despite the atypical changes of some major elements, e.g., higher $\mathrm{K}_{2} \mathrm{O}$ content in the mesomylonite compared to the protolith (Table 1), secondary metasomatic addition of $\mathrm{K}$ into the system is not assumed. The changes are rather considered as lateral element migration in the shear zone system (Hippertt, 1998; Arancibia \& Morata, 2005). This fact is indicated by the erratic trend of $\mathrm{K}$ behaviour, which is situated below the isocon in some deformed rocks and above in others (Fig. 8). The increased potassium content in mesomylonite is connected to the higher $\mathrm{Rb}$ content and the moderately higher $\mathrm{Ba}$ concentration against the precursor or the protomylonite. The higher value of potassium concentration may be related to K-feldspar decomposition during the deformation process and to significant white mica formation. An increased Ba content in K-feldspars of the biotite granodiorites from the Bujanová Complex were described by Bónová (2006).

The variable REE content in the deformed rocks studied probably is connected to disintegration of some accessory minerals that are commonly present in the biotite granodiorite (apatite, zircon, allanite, titanite etc.). The distribution of REE (Fig. 9), relatively constant content of $\mathrm{P}_{2} \mathrm{O}_{5}$ and $\mathrm{Hf}$ concentration which are significant for apatite and zir- 
con, respectively, perhaps even Ta content which is a good proxy for titanite (Noyes et al., 1983), suggesting the presence of accessory minerals in the mesomylonite. The phosphorus content seemingly decreases (Table 1) in the mesomylonite, especially in the ultramylonite. This would reflect either a decrease of apatite or it could be caused by the quartz dilution effect. On the other hand, the position of $\mathrm{P}$ directly on the isocon (Fig. 8) in all specimens studied indicates its persistence in the system. It is clear from Figure 8 (C-F) that the immobile elements were diluted during the alteration process because they lie below a line of constant mass.

The slight increase of HREE in protomylonites compared to the protolite probably is connected to the slightly higher zircon (+/ - titanite) content, which is documented by small modification in $\mathrm{Zr}$ and Ta concentrations (Fig. 8A, G, H). As noted above, allanite is an important REE- (mainly LREE) bearing mineral in the protolite. The absence of allanite, as well as the diminished content of other accessory minerals due to their breakup during deformation and alteration in the ultramylonite, correspond to the REE decrease in this type of deformed rock (Table 1 ).

Taking into account the $\mathrm{SiO}_{2}$ gain and following accruement of the modal quartz content, it is clear that fluid-enhanced silicification is likely to have accompanied the mylonitisation process. Application of the normalised mylonite/protolith ratio plots (Fig. 10) for selected major oxides, to help determine the bulk changes (Condie \& Sinha, 1996), indicates that the Rolovská shear zone belongs to the volume-gain/isovolume category. These facts signal that extensional structures relating to the Veporic unit post-collisional unroofing and simultaneous shear zone opening as well as their strong hydrothermal silicification overprinted earlier thrust-related fabrics. Consequently, the tectonites in the shear zone were modified in the brittle-ductile regime again during NW-SE strike-slip movements. The product of this deformation stage is the stretching lineation trace visible on the mylonite foliation planes.

\section{Conclusions}

The granitoid mylonites of the Rolovská shear zone in the Čierna hora Mts passed through a complex polystage development during several Hercynian and Alpine tectonothermal events. The classical mylonite development and almost regional mylonite extension is typical of the Bujanová complex granitoids.
The mylonites of the section studied are macroscopically foliated rocks with stretching lineation on the foliation planes. Following the matrix/porphyroclasts ratio different structural types of mylonites were distinguished. The important feature of the mylonite microfabric studied is the marked grainsize reduction from the margins towards the shear zone centre.

The modal mineralogy of the profile rocks also changes considerably. The protolith's (biotite granodiorite) major minerals are feldspars, quartz and micas. The bulk modal mineralogy of the protomylonites is similar to that of the undeformed precursor. The significant plagioclase decrease and strong quartz and mica gain is characteristic of the mesomylonites and ultramylonites. The character and distribution of deformation relates to the modal mineralogy of the tectonites in the section studied. As the feldspars in low-grade conditions deform in brittle manner, so the deformation in the protomylonites with high feldspar content have a predominantly brittle character. In contrast, the overall deformation in the mesomylonites and ultramylonites is ductile due to the high quartz and mica content.

The chemical changes in the major oxide abundances reflect modal changes of the mylonitised rocks. The deformation conditions allowed lateral element migration in the shear zone system. Some processes required an environment abundant in fluids. The chemical composition of the biotite granodiorite protomylonites is nearly identical to that of the protolith. Clear chemical changes occur in mesomylonites and also in ultramylonites. The most visible chemical change is the $\mathrm{SiO}_{2}$ gain and increase in modal quartz in mesomylonites and ultramylonites. It is evident that the mylonitisation process was accompanied by strong fluid-enhanced silicification and simultaneous volume gain of the central parts of the shear zone.

\section{Acknowledgements}

This study was funded by VEGA Slovak Agency, project No. 1-4031-07 and by the Project implementation Research centre for efficient integration of the renewable energy sources, ITMS. 26220220064 supported by the Research \& Development Operational Programme funded by the ERDF. 


\section{References}

Ague, J.J., 1991. Evidence for major mass transfer and volume strain during regional metamorphism of pelites. Geology 19, 855-858.

Ague, J.J., 1994. Mass transfer during Barrovian metamorphism of pelites, south-central Connecticut. Evidence for changes in composition and volume. American Journal of Science 294, 989-1057.

Ague, J.J. \& van Haren, J.L.M., 1996. Assessing metasomatic mass and volume changes using the bootstrap, with application to crustal hydrothermal alteration of marble. Economic Geology 91, 1169-1182.

Arancibia, G. \& Morata, D., 2005.Compositional variations of syntectonic white-mica in low-grade ignimbritic mylonite. Journal of Structural Geology 27, 745-767.

Baumgartner, L.P. \& Olsen, S.N., 1995. A least-squares approach to mass transport calculations using Isocon method. Economic Geology 90, 1261-1270.

Bell, T.H. \& Cuff, C., 1989. Dissolution, solution transfer, diffusion versus fluid flow and volume loss during deformation/metamorphism. Journal of Metamorphic Geology 7, 425-447.

Berthé, D., Choukroune, P. \& Jegouzo, P., 1979. Orthogneiss, mylonite and non coaxial deformation of granites. The example of the South Armorican Shear Zone. Journal of Structural Geology 1, 31-42.

Bezák, V., 1994. Návrh nového členenia kryštalinika Západných Karpát na základe rekonštrukcie hercýnskej tektonickej stałby [Proposal of the new dividing of the West Carpathian crystalline based on the hercynian tectonic building reconstruction]. Mineralia Slovaca 26, 1-6.

Bónová, K., 2006. Geochemicko-mineralogicko-petrografická charakteristika granitoidov Braniska a Čiernej hory a ich petrologická a geotektonická interpretácia [Geochemical-mineralogical-petrographical characteristics of the Branisko and the Cierna hora Mts granitoides and their petrologic and geotectonic interpretation]. PhD. Theses. TU of Košice, 131 pp.

Broska, I., Petrík, I., Be'eri-Shlevin, Y., Majka, J. \& Bezák, V., 2013. Devonian/Mississippian I-type granitoids in the Western Carpathians. A subduction-related hybrid magmatism. Lithos 162-163, 27-36.

Christiansen, P.P. \& Pollard, D.D., 1997. Nucleation, growth and structural development of mylonitic shear zones in granitic rock. Journal of Structural Geology 19, 1159-1172.

Condie, D. \& Sinha, A.K., 1996. Rare earth and other trace element mobility during mylonitization. A comparison of the Brevard and Hope Valley shear zones in the Appalachian Mountains, USA. Journal of Metamorphic Geology 14, 213-226.

Evensen, N.M., Hamilton, P.J. \& O'Nions, R.K., 1978. Rare-earth abundances in chondritic meteorites. Geochimica et Cosmochimica Acta 42, 1199-1212.

Farkašovský, R., 2005. Mikrostavba mylonitov rolovskej strižnej zóny, veporikum Čiernej hory [Microstructure of the Rolovská shear zone mylonites, Čierna hora Mts Veporicum]. Mineralia Slovaca 37, 227-229.
Farkašovský, R., 2006. Kinematika a mikrostavba krehko-duktilných tektonitov v strižných zónach veporika Čiernej hory [Kinematics and microstructure of the brittle-ductile tectonites in the shear zones of the Cierna hora Mts Veporicum]. PhD. Theses. TU of Košice, 182 pp.

Farkašovský, R., 2013. Shear zones and mylonite microfabric in the Čierna hora Mts (Eastern Slovakia). Monograph. Líceum Kiadó, Eger, 58 pp.

Goddard, J. \& Evans, J., 1995. Chemical changes and fluid-rock interaction in faults of crystalline thrust sheets, northwestern Wyoming, U.S.A. Journal of Structural Geology 17, 533-547.

Goncalves, P., Oliot, E., Marquer, D. \& Connolly, D., 2012. Role of chemical processes on shear zone formation: an example from the Grimsel metagranodiorite (Aar massif, Central Alps). Journal of Metamorphic Geology 30, 703-722.

Goodwin, L.B. \& Wenk, H.R., 1995. Development of phyllonite from granodiorite. Mechanisms of grain-size reduction in the Santa Rosa mylonite zone, California. Journal of Structural Geology 17, 689-707.

Grant, J.A., 1986. The Izocon Diagram A Simple Solution to Gresens' Equation for Metasomatic Alteration. Economic Geology 81, 1976-1982.

Grant, J.A., 2005. Isocon Analysis. A brief review of the method and applications. Physics and Chemistry of the Earth 30, 997-1004.

Guermani, A. \& Pennacchioni, G., 1998. Brittle precursors of plastic deformation in a granite. An example from the Mont Blanc massif (Helvetic, western Alps). Journal of Structural Geology 20, 135-148.

Gueydan, F., Leroy, Y.M., Jolivet, L. \& Agard, P., 2003. Analysis of continental midcrustal strain localization induced by microfracturing and reaction-softening. Journal of Geophysical Research - Solid Earth 108, 19782012.

Halama, R., Konrad-Schmolke, M., Sudo, M., Marschall, H.R. \& Wiedenbeck, M., 2014. Effects of fluid-rock interaction on 40Ar/39Ar geochronology in high-pressure rocks (Sesia-Lanzo Zone, Western Alps). Geochimica et Cosmochimica Acta 126, 475-494.

Hippertt, J.F. \& Hongn, F.D., 1998. Deformation mechanisms in the mylonite/ultramylonite transition. Journal of Structural Geology 20, 1435-1448.

Hippertt, J.F., 1994. Grain boundary microstructures in micaceous quartzites: significance for fluid movement and deformation processes in low metamorphic grade shear zones. Journal of Geology 102, 331-348.

Hippertt, J., 1998. Breakdown of feldspar, volume gain and lateral mass transfer during mylonitization of granitoid in a low metamorphic grade shear zone. Journal of Structural Geology 20, 175-193.

Jacko, S., 1975. Litologicko-štruktúrny vývoj južnej časti kryštalinika Bujanovského masívu [Lithological-structural development of the Bujanová crystalline massive southern part]. PhD. Theses. TU of Košice, 304 pp.

Jacko, S., 1979. Geologický profil pásmom Čiernej hory a jeho styku s gemerikom [Geological cross-section of the Čierna Hora Mts and the Gemericum contact zone]. [In:] M. Mahel' (Ed.): Tektonické profily Západ- 
ných Karpát [Tectonic cross-sections of the Western Carpathians]. GÚDŠ, Bratislava, 185-193.

Jacko, S., 1985. Litostratigrafické jednotky kryštalinika Čiernej hory [Litostratigraphic units of the Čierna Hora Mts crystalline complex]. Geologické Práce, Správy 82, 127-133.

Jacko, S., 1988. Postavenie Braniska a Čiernej hory v kontexte centrálnych Západných Karpát [The position of the Branisko and Ćierna Hora Mts in the central Westcarpathian context]. Zbornik Vedeckých Prác VŠT $v$ Košiciach, 173-185.

Jacko, S., 2007. Successive relationships of tectonometamorphic parageneses in the Branisko and Čierna Hora Mts (Western Carpathians). Acta Geologica Universitatis Comenianae 1, 33-40.

Jacko, S. \& Baláž, B., 1993. Nové poznatky o metalogenéze Čiernej hory [New knowledge about Čierna Hora Mts metallogenese]. Mineralia Slovaca 25, 323-326.

Jacko, S., Farkašovský, R. \& Schmidt, R., 2001. Veporic basement of the Branisko and Čierna Hora Mts. An example for Hercynian and Alpine polystage evolution. [In:] V. Bezák (Ed.): Western Carpathian and European Hercynides. Konferencie, Sympóziá, Semináre, ŠGÚDŠ, Bratislava, 18-20.

Jacko, S., Korikovskij, S.P. \& Boronichin, V.A., 1990. Rovnovážne asociácie rúl a amfibolitov komplexu Bujanovej, Čierna hora [Equilibrium assemblages of gneisses and amphibolites of the Bujanová complex, Ćierna Hora Mts]. Mineralia Slovaca 22, 231-239.

Jacko, S., Vozár, J. \& Polák, M., 1995. Nové poznatky o geologickej stavbe Braniska a Čiernej hory [New knowledge about geological structure of the Branisko and the Čierna Hora Mts]. Mineralia Slovaca 27, 417-418.

Jacko, S., Sasvári, T., Zacharov, M., Schmidt, R. \& Vozár, J., 1996. Contrasting styles of Alpine deformations at the eastern part of the Veporicum and Gemericum units, Western Carpathians. Slovak Geological Magazine 2, 151-164.

Johnson, S.E., Marsh, J.H., Vernon, R.H., 2008. From tonalite to mylonite: coupled mechanical and chemical processes in foliation development and strain localization. Journal of the Virtual Explorer 30, 3-33.

Kamenický, J., 1977. Geological-petrographical relations of granodiorites from Čierna Hora Mts. Acta Geologica et Geographica Universitatis Comenianae 32, 81-110.

Kohút, M., Frank, W. \& Petro, M., 2000. The Sparistá dolina Granitic Mylonites - the Products of the Alpine Deformation. Slovak Geological Magazine 6, 347-361.

Korikovskij, S.P., Jacko, S. \& Boronichin, V.A., 1989. Alpine anchimetamorphism of Upper Carboniferous sandstones from the sedimentary mantle of the Čierna Hora Mts crystalline complex (Western Carpathians). Geologica Carpathica 40, 579-598.

Korikovskij, S.P., Jacko, S. \& Boronichin, V.A., 1990. Faciálne podmienky varískej prográdnej metamorfózy v lodinskom komplexe kryštalinika Čiernej hory [Facial conditions of Variscan prograde metamorphosis in the Lodina complex of Cierna Hora crystalline, Eastern Slovakia]. Mineralia Slovaca 22, 225-230.
Krist, E., Korikovskij, S.P., Putiš, M., Janák, M. \& Faryad, S.W., 1992. Geology and Petrology of Metamorphic Rocks of the West Carpathians Crystalline Complexes. Comenius University, Bratislava, 324 pp.

Lee, V.W., Mackwell, S.J. \& Branley, S.L., 1991. The effect of fluid chemistry on wetting textures in Novaculite. Journal of Geophysical Research 96, 10023-10037.

Lin, A., 1999. S-C cataclasite in granitic rocks. Tectonophysics 304, 257-273.

Lister, G.S. \& Snoke, A.W., 1984. S-C mylonites. Journal of Structural Geology 6, 617-639.

Maluski, H., Rajlich, P. \& Matte, P., 1993. ${ }^{40} \mathrm{Ar}-{ }^{39} \mathrm{Ar}$ dating of the Inner Carpathians Variscan basement and Alpine mylonitic overprinting. Tectonophysics 223, 313-337.

Mancktelow, N. \& Pennacchioni, G., 2005. The control of precursor brittle fracture and fluid-rock interaction on the development of single and paired ductile shear zones. Journal of Structural Geology 27, 645-661.

Miko, O., Kátlovský, V. \& Cubínek, J., 1982. Changes in mineral and chemical composition of some Veporid granitoid rocks, due to Alpine dislocation metamorphism. [In:] E. Krist \& A. Mihaliková (Eds), Metamorphic processes in the Western Carpathians. GÚDŠ, Bratislava, 45-52.

Moore, P.B., Bell, P.M., Hem, J.D., 1970. Aluminium. [In:] K.H. Wedepohl (Ed.), Handbook of Geochemistry. Vol. II/2. Springer, Berlin, 13G-13L.

Németh, Z., 2001. Petrotectonics of the ductile shear zones of Gemericum. PhD. Thesis. Univerzita Komenského, Bratislava, 98 pp.

Németh, Z., Putiš, M. \& Grecula, P., 2000. Tectonic evolution of Gemericum (the Western Carpathians) outlined by the results of petrotectonic research. Mineralia Slovaca 32, 169-172.

Noyes, H.J., Frey, H.A., Wones, D.R., 1983. A tale of two plutons. Geochemical evidence bearing on the origin and differentiation of the Red Lake and Eagle Peak Plutons, central Sierra Nevada, California. Journal of Geology 91, 487-509.

Oliot, E., Goncalves, P. \& Marquer, D., 2010. Role of plagioclase and reaction softening in a metagranite shear zone at mid-crustal conditions (Gotthard Massif, Swiss Central Alps). Journal of Metamorphic Geology 28, 849-871.

Passchier, C.W., 1982. Pseudotachylyte and the development of ultramylonite bands in the Saint-Barthelemy Massif, French Pyrenees. Journal of Structural Geology 4, 69-79.

Passchier, C.W. \& Trouw, R.A.J., 1996.Microtectonics. Springer, Berlin, 289 pp.

Pennacchioni, G. \& Mancktelow, N., 2007. Nucleation and initial growth of a shear zone network within compositionally and structurally heterogeneous granitoids under amphibolite facies conditions. Journal of Structural Geology 29, 1757-1780.

Plašienka, D., 1999. Tektonochronológia a paleotektonický model jursko-kriedového vývoja centrálnych Západných Karpát [Tectonochronology and paleotectonic model of the Jurassic-Cretaceous evolution of Central Western Carpathians]. VEDA, Bratislava, 127 pp. 
Platt, J.P., 1984. Secondary cleavages in ductile shear zones. Journal of Structural Geology 6, 439-442.

Platt, J.P. \& Vissers, R.L.M., 1980. Extensional structures in anisotropic rocks. Journal of Structural Geology 2, 397-410.

Polák, M., Jacko, S., Vozárová, A., Vozár, J., Gross, P., Harčár, J., Zacharov, M., Baláž, B., Liščák, P., Malík, P., Zakovič, M., Karoli, S. \& Kaličiak, M., 1997. Vysvetlivky ku geologickej mape Braniska a Čiernej hory 1 : 50000 [Explanations to geological map of Branisko and Čierna Hora Mts 1 : 50 000]. Vydavatel'stvo Dionýza Štúra, Bratislava, 201 pp.

Pryer, L.L., 1993. Microstructures in feldspars from a major crustal thrust zone, the Grenville Front, Ontario, Canada. Journal of Structural Geology 15, 21-36.

Putiš, M., Unzog, W., Wallbrecher, E. \& Fritz, H., 1997. Mylonitization and chemical mass-transfer in granitoid rocks of the Vepor pluton near the Cretaceous Pohorelá thrust, Veporic unit, central Western Carpathians. [In:] P. Grecula, D. Hovorka \& M. Putiš (Eds): Geological evolution of the Western Carpathians. Mineralia Slovaca - Monograph, Bratislava, 197-214.

Roberts, D. \& Nissen, A.L., 2006. Geochemical changes accompanying mylonitisation of granite at the base of the Helgeland Nappe Complex, Nord-Trøndelag, central Norway. Norges Geologiske Under Søkelse Bulletin 446, 35-41.

Rutter, E.H., 1999. On the relationship between the formation of shear zones and the form of the flow law for rocks undergoing dynamic recrystallization. Tectonophysics 303, 147-158.

Sassier, C., Boulvais, P., Gapais, D., Capdevila, R. \& Diot, H., 2006. From granitoid to kyanite-bearing micaschist during fluid-assisted shearing (Ile d'Yeu, France). International Journal of Earth Science 95, 2-18.

Selverstone, J., Morteani, G. \& Staude, J.M., 1991. Fluid channelling during ductile shearing: transformation of granodiorite into aluminous schist in Tauern Window Eastern Alps. Journal of Metamorphic Geology 9, 419-431.

Sibson, R.H., 1977. Fault rocks and fault mechanisms. Journal of Geological Society London 133, 191-213.
Simpson, C., 1985. Deformation of granitic rocks across the brittle-ductile transition. Journal of Structural Geology 7, 503-511.

Steyrer, H.P. \& Sturm, R., 2002. Stability of zircon in a low-grade ultramylonite and its utility for chemical mass balancing. The shear zone at Miéville, Switzerland. Chemical Geology 187, 1-19.

Stunitz, H. \& Tullis, J., 2001. Weakening and strain localization produced by syn-deformational reaction of plagioclase. International Journal of Earth Sciences 90, 136-148.

ten Grotenhuis, S.M., Trouw, R.A.J. \& Passchier, C.W., 2003. Evolution of mica fish in mylonitic rocks. Tectonophysics 372, 1-21.

Trouw, R.A.J., Passchier, C.W. \& Wiersma, D.J., 2010. Atlas of mylonites and related microstructures. Springer, Berlin, 313 pp.

Tullis, J. \& Yund, R.A., 1989. Hydrolytic weakening of quartz aggregates: The effects of water and pressure on recovery. Geophysical Research Letters 16, 1343-1346.

Tullis, J., Yund, R. \& Farver, J., 1996. Deformation-enhanced fluid distribution in feldspar aggregetes and implications for ductile shear zones. Geology 24, 63-66.

van der Straaten, F., Halama, R., John, T., Schenk, V., Hauff, F. \& Andersen, N., 2012. Tracing the effects of high-pressure metasomatic fluids and seawater alteration in blueschist-facies overprinted eclogites: Implications for subduction channel processes. Chemical Geology 292-293, 69-87.

Wibberley, C., 1999. Are feldspar-to-mica reactions necessarily reaction-softening processes in fault zones? Journal of Structural Geology 21, 1219-1227.

Wintsch, R.P., Christoffersen, R. \& Kronenberg, A.K., 1995. Fluid-rock reaction weakening of fault zones. Journal of Geophysical Research - Solid Earth, 100, 1302113032.

Manuscript received: 3 September 2015 Revision accepted: 18 May 2016 